\title{
Facility Effluent Monitoring Plan for the Plutonium-Uranium Extraction Facility
}

Date Published

December 1997

Prepared for the U.S. Department of Energy

Fluor Daniel Hanford, Inc.

P.O. Box 1000

Richland, Washington

Hanford Management and Integration Contractor for the

U.S. Department of Energy under Contract DE-AC-0696-RL13200 


\section{RELEASE AUTHORIZATION}

\section{Document Number: HNF-EP-0468-4}

Document Title: Uranium Extraction Facility

Facility Effluent Monitoring Plan for the Plutonium

This document; reviewed in accordance with DOE Order 1430.1D, "Scientific and Technical Information Management," and DOE G 1430.1D-1, "Guide to the Management of Scientific and Technical Information," does not contain classified or sensitive unclassified information and is:

\section{APPROVED FOR PUBLIC RELEASE}
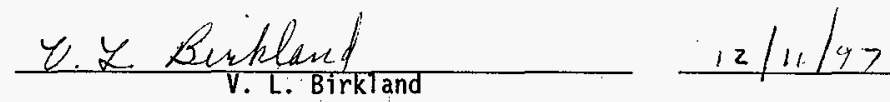

Lockheed Martin Services, Inc.

Document Control/Information Clearance

Reviewed for Applied Technology, Business Sensitive, Classified, Copyrighted, Expont Controlled, Patent, Personat/private, Proprietary.

Protected CRADA, Trademark, Unclassified Controlled Nuclear information.

Tradomark Disclaimer. Roferenco herein to any specific commercial product, process, or service by trade name, trademark, manufacturex, or otherwise, does not necessarily constituto or imply its endorsement, recommendation, or favoring by the United States Government or any agency thereof or its contractors or subcontractors. The views and opinions of authers oxpressed herein do not necossarily stato or reflect those of the United States Government or any agency thereof. This roport has boen reproduced from the best available copy.

Printod in the United States of Amorica.

Available to the U.S. Department of Energy and its contractors from the U.S. Department of Energy Office of Sciontific and Technical Information, P.O. Box 62, Oak Ridge, TN 37831; Tolophone: 423/576-8401.

Available to the public from the U.S. Department of Commexce National Technical Information Service, 6285 Port Royal Road, Springfield, VA 22161; Telephone: 703/487-4650. 


\section{Facility Effluent Monitoring Plan for the Plutonium-Uranium Extraction Facility}

Prepared for the U.S. Department of Energy

Fluor Daniel Hanford, Inc.

Richland, Washington

Hanford Management and Integration Contractor for the

U.S. Department of Energy under Contract DE-AC-0696-RL13200 
TRADEMARK DISCLAMER

Reference herein to any specific commercial product, process, or service by trede name, trademark, manufacturer, or otherwise, does not necesserily constitute or imply its endorsement, recommendation, or favoring by the United States Government or any agency thereof or its centractors or sibcontrectors.

This report has been reproduced from the best available copy. Available in paper copy and microfiche.

Available to the U.S. Department of Energy and its contractors from

U.S. Department of Energy

Oftice of Scientific and Technical Information (OSTI)

P.O. Box 62

Oak Ridge, TN 37831

(615) 576-8401

Available to the public from the U.S. Department of Commerce National Technical Information Service (NTIS)

5285 Port Royal Road

Springfield, VA $2216 i$

(703) $487-4650$

Printed in the United Stetes of Americe

DISCLM-5.CHP (8-95) 


$$
\text { HNF-EP-0468-4 }
$$

Plutonium-Uranium Extraction Plant

Prepared by:

Approved by:

Approved by:

Approved by:

Reviewed by:

Reviewed by:

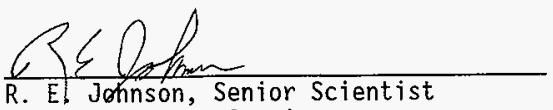

WMH Air \& Water Services

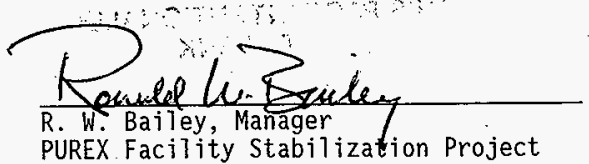

Erwin. Gran

E. M. Greaser, Manager

WMH Air \& Water Services

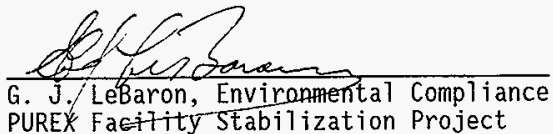

PURE K Freity Stabilization Project

L. P. Diediker, Team Leader WMH Air \& Water Services.

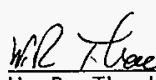

W. R. Thackaberry

WM H Health \& Safety

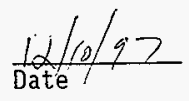

$\frac{12 / 10 / 97}{\text { Date }}$

$\frac{12 / 10 / 97}{\text { Date }}$

$10 \operatorname{PEC} 97$

Date

$\frac{12-\infty-8 \geq}{\text { Date }}$

$\frac{12-10-92}{\text { Date }}$ 
THIS PAGE INTENTIONALLY LEFT BLANK 


\title{
HNF-EP-0468-4
}

\section{FACILITY EFFLUENT MONITORING PLAN FOR THE PLUTONIUM-URANIUM EXTRACTION FACILITY}

\begin{abstract}
A facility effluent monitoring $\mathrm{plan}$ is required by the U.S. Department of Energy in DOE Order $5400.1^{\text {a }}$ for any operations that involve hazardous materials and radioactive substances that could impact employee or public safety or the environment. This document is prepared using the specific guidelines identified in "A Guide for Preparing Hanford Site Facility Effluent Monitoring Plans", WHC-EP-0438-01 ${ }^{\mathrm{b}}$. This facility effluent monitoring $\mathrm{plan}$ assesses effluent monitoring systems and evaluates whether these systems are adequate to ensure the public health and safety as specified in applicable federal, state, and local requirements.
\end{abstract}

This facility effluent monitoring plan will ensure long-range integrity of the effluent monitoring systems by requiring an update whenever a new. process or operation introduces new hazardous materials or significant radioactive materials. This document must be reviewed annually even if there are no operational changes, and it must be updated, at a minimum, every 3 years.

a DOE Order 5400.1, "General Environmental Protection Program".

b WHC-EP-0438-01, "A Guide for Preparing Hanford Site Facility Effluent Monitoring Plans", Westinghouse Hanford Company, Richland, Washington, 1992. 
HNF-EP-0468-4

This page intentionally left blank. 
HNF-EP-0468-4

CONTENTS

ABSTRACT ..................................

METRIC CONVERSION CHART .................. X

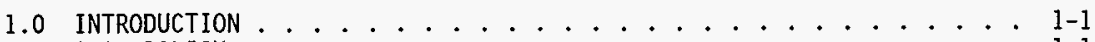

1.1 POLICY . . . . . . . . . . . . . . 1-1

1.2 PURPOSE . . . . . . . . . . . . . . . . . . 1-1

1.3 SCOPE . . . . . . . . . . . . . . . 1-1

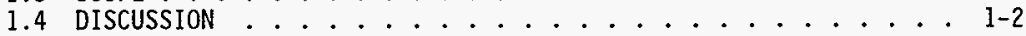

2.0 FACILITY DESCRIPTION ...................... 2-1

2.1 BRIEF FACILITY PHYSICAL LAYOUT ............. 2-1

2.1 .1 202-A Building ................. 2-1

2.1.2 Effluent Monitoring Building .......... 2-2

2.1:3 Rajlroad Tunnel and Storage Tunnels ......... 2-2

2.1 .4 291-AE Building .............. 2-2

2.2 BRIEF PROCESS DESCRIPTION ............. . 2-2

2.3 PRESENT AND FUTURE ACTIVITIES . . . . . . . . . 2-3

2.4 IDENTIF ICATION/CHARACTERIZATION OF POTENTIAL SOURCE TERMS . . . $2-3$

2.4.1 Gaseous Effluents .............. 2-3

2.4 .2 Liquid Effluents ............... 2-3

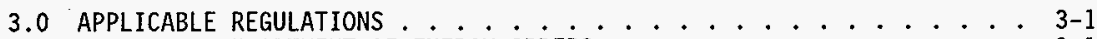

3.1 U.S. DEPARTMENT OF ENERGY ORDERS ............. . . 3-1

3.2 FEDERAL REGULATIONS ................. . . . . . .

3.2.1 Environmental Protection Agency Regulations on

National Emission Standards for Hazardous Air

Pollutants 40 CFR $61 \ldots . . . . . .3-1$

3.2 .2 Reportable Quantities 40 CFR $302 \ldots . . . . .3-2$

3.3 STATE REGULATIONS ................... 3-2

3.3.1 Washington State Ambient Air Qual ity Standard and

3.3.2 Groundwater Protection. . . . . . . . . . 3-3

3.3.3 Dangerous Waste Regulations ........... 3-3

3.4 LOCAL REGULATIONS .................. . . . . . . .

3.5 AIR EMISSIONS . . . . . . . . . . . . . . . 3-3

3.6 LIQUID EFFLUENTS . . . . . . . . . . . . . . . . . . . . 3-4

4.0 IDENTIFICATION/CHARACTERIZATION OF EFFLUENT STREAMS ...... 4-1

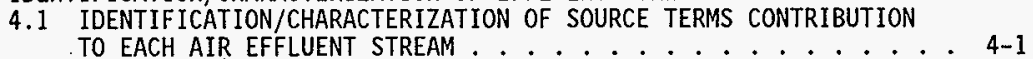

4.1.1 Routine Operations .............. . 4-1

4.1.2 Upset Operating Conditions ............ . 4-2

4.1.3 Dispersion Modeling ............. 4-2

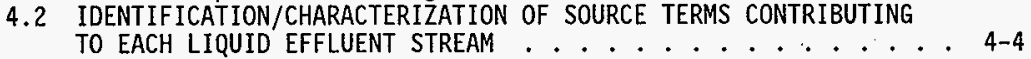

5.0 EFFLUENT POINT OF DISCHARGE DESCRIPTION . . . . . . . 5-1

5.1 AIR EFFLUENTS . . . . . . . . . . . . . . 5-1

5.2 WATER EFFLUENTS ..................... 
HNF-EP-0468-4

\section{CONTENTS (cont)}

6.0 EFFLUENT MONITORING/SAMPLING SYSTEM DESIGN CRITERIA . . . . . . $6-1$

6. 1 EXISTING FACILITIES . . ................. 6-1

6.2 AIRBORNE EFFLUENT SAMPLING AND MONITORING SYSTEM DESIGN

CRITERIA . . . . . . . . . . . . . . . . . . . . 6-1

6.3 LIQUID EFFLUENT SAMPLING AND MONITORING SYSTEM DESIGN

CRITERIA ..................... 6-. 6

7.0 CHARACTERIZATION OF CURRENT EFFLUENT MONITORING SYSTEM . . . . . . 7-1

7.1 AIR EFFLUENT MONITORING SYSTEM DESCRIPTION AND

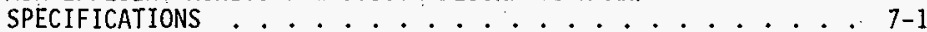

7.1.1 Monitoring/Sampling Requirements and Criteria . . . 7-1

7.1.2 Existing Air Effluent Monitoring/Sampling System . . . 7-1

7.2 REMAINING STACKS .............. 7-2

7.3 AIR EFFLUENT SAMPLING PROGRAM .............. $7-2$

8.0 HISTORICAL MONITORING/SAMPLING DATA FOR EFFLUENT STREAMS $. . . \quad 8-1$

8.1 AIR EFFLUENTS ................... 8-1

8.2 LIQUID EFFLUENTS .................. 8-1

9.0 SAMPLE ANALYSIS . . . . . . . . . . . . . . . . 9-1

10.0 NOTIFICATION AND REPORTING REQUIREMENTS .............. . . 10-1

10.1 OCCURRENCE CATEGORIZATION, NOTIFICATION, AND REPORTING . . 10-1

10.2 FEDERAL REQUIREMENTS .................... . . . $10-1$

10.2.1 Resource Conservation and Recovery Act

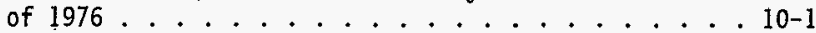

10.2.2 Comprehensive Environmentai Response,

Compensation, and Liability Act of 1980 . . . . . 10-1

10.2.3 National Emission Standards for Hazardous Air

Pollutants .................. 10-1

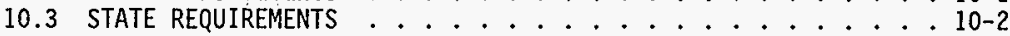

10.3.1 Generator Reporting .............. . . 10-2

10.3.2 Facility Reporting ............... . . 10-2

11.0 INTERFACE WITH NEAR-FACILITY MONITORING . . . . . . ..... 11-1

11.1 PURPOSE ....................... . . . . . . . . . . . .

11.2 BASIS . . . . . . . . . . . . . . 11-2

11.3 MEDIA SAMPLED AND ANALYSES PERFORMED ........... . . 11-2

11.4 LOCATIONS . . . . . . . . . . . . . . . 11-2

11.5 PROGRAM REVIEW ...................... ... 11-3

11.6 SAMPLER DESIGN ................... ... 11-3

11.7 COMMUNICATION . . . . . . . . . . . . . . . . . 11-3

11.8 REPORTS . . . . . . . . . . . . . . . . 11-3

12.0 QUALITY ASSURANCE . . . . . . . . . . . . . . . . . 12-1

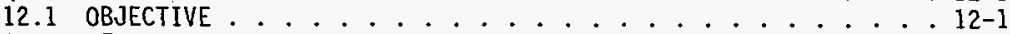

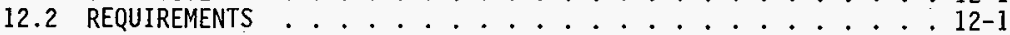

13.0 INTERNAL AND EXTERNAL PLAN REVIEW ................... . . . . . . . 
HNF-EP-0468-4

CONTENTS (cont)

14.0 COMPLIANCE ASSESSMENT ................. 14-1

14.1 COMPLIANCE ASSESSMENT . . . . . . . . . . . 14-1

14.1.1 Comparison of Instrument Specifications with

Required Standard............... 14-1

14.1.2 Comparison of Instrument Specifications with

Monitoring Criteria .............. 14-1

14.1.3 Comparison of Instrument Specifications with

Effluent Characteristics ........... . 14-1

14.1.4 Comparison of Projected Effluent Characteristics

with HistoricaT Data ............. . . . . . .

14.1.5 Comparison of Effluent Monitoring Capabilities

14.2 EXEMPTIONS . . . . . . . . . . . . . . . . .

14.3 SYSTEM UPGRADES REQUIRED FOR COMPLIANCE . . . . . . . . . 14-2

14.4 CLEAN AIR ACT REQUIREMENTS ............. . . . . . .

15.0 SUMMARY AND CONCLUSIONS ...... 15-1

15.1 MONITORING AND SAMPLING REQUIREMENTS FOR AIR

EFFLUENTS . . . . . . . . . . . . . . 15-1

15.2 SYSTEMS UPGRADES FOR AIR MONITORING/SAMPLING . . . . . . 15-1

16.0 REFERENCES . . . . . . . . . . . . . . . 16-1

FIGURES

2-1. Location of the Plutonium-Uranium Extraction P1ant ........ F2-1

2-2. Plutonium-Uranium Extraction Plant Plot Plan ......... F2-2

$2-3$. 202-A Building .................................

5-1. Plutonium-Uranium Extraction Plant Exhaust Stacks ........ F5-1

\section{TABLES}

4-1. Plutonium-Uranium Extraction Plants Stack Exhaust Data . . . . 4-5

4-2. CAP-88 Unit Dose Factors for the Nearest Receptor

Affected by Radionuclide Air Emissions from PUREX

(200 East Area) . . . . . . . . . . . . . . 4-5

4-3. Individual Radionuclide Doses to Maximally Exposed

Individual for 1996 from $291-A-1 . \ldots$. . . . . . . . . .

4-4. Potential Doses to the Maximally Exposed Individual

from an Unmitigated Release . . . . . . . . . . . 4-6

4-5. Potential Individual Radionucl ide Doses to the Maximally $\ldots . . . .4-6$
Exposed Individual from an Unmitigated Release. . . . .

7-1. Radioactive Sampling Requirements for Plutonium-Uranium $\ldots . . .4-6$

7-2. Monitoring/Sampling and Analysis Program for Air Effluents $\ldots . .7-3$ 
HNF-EP-0468-4

\section{TERMS}

ABCASH

ANSI

ASTM

BHI

CERCLA

CFR

DOE

DOE-RL

DP

Ecology

EDE

EMP

EPA

ERS

ES\&H

FDH

FEMP

HEPA

HNF

HVAC

$M / S$

MEI

NFM

NESHAP

PHMC

PNL

PNNL

PSD

PUREX

$Q A$

QAPjP

QAPP

RCRA

S\&M

SAMCONS

SQA
Automated Bar Coding of Air Samples at Hanford American National Standards Institute

American Society for Testing and Materials

Bechtel Hanford, Inc.

Comprehensive Environmental Response, Compensation, and Liability Act of 1980

Code of Federal Regulations

U.S. Department of Energy

U.S. Department of Energy, Richland Operations Office differential pressure

Washington State Department of Ecology

effective dose equivalent

environmental monitoring plan

U.S. Environmenta] Protection Agency

environmental release summary database

Environmental Safety and Health

F]uor Daniel Hanford, Inc.

facility effluent monitoring plan

high-efficiency particulate air (filter)

Hanford Nuclear Facility (document identifier)

heating, ventilation, and air conditioning

monitoring/sampling

maximally exposed individual

near-facility monitoring

National Emission Standards for Hazardous Air

Pollutants

Project Hanford Management Contract

Pacific Northwest Laboratory

Pacific Northwest National Laboratory

prevention of significant deterioration

Plutonium-Uranium Extraction (Plant)

quality assurance

quality assurance project plan

quality assurance program plan

Resource Conservation and Recovery Act of 1976

surveillance and maintenance

sampling and monitoring control system

software quality assurance 


\section{HNF-EP-0468-4}

\section{TERMS (cont)}

TLD

TSD

WAC

WDOH

WHC thermal luminescent dosimeter treatment, storage, and/or disposal

Washington Administrative Code

Washington State Department of Health Westinghouse Hanford Company 


\section{METRIC CONVERSION CHART}

Into metric units

Out of metric units

\begin{tabular}{|c|c|c|c|c|c|}
\hline If you know & $\begin{array}{c}\text { Multipiy } \\
\text { by }\end{array}$ & To get & If you know & $\begin{array}{c}\text { Muttiply } \\
\text { by }\end{array}$ & To get \\
\hline \multicolumn{3}{|c|}{ Length } & \multicolumn{3}{|c|}{ Length } \\
\hline inches & 25.40 & millimeters & millimeters & 0.0393 & inches \\
\hline inches & 2.54 & centimeters & centimeters & 0.393 & inches \\
\hline feet & 0.3048 & meters & meters & 3.2808 & feet \\
\hline yards & 0.914 & meters & meters & 1.09 & yards \\
\hline miles & 1.609 & kilometers & kilometers & 0.62 & miles \\
\hline \multicolumn{3}{|c|}{ Area } & \multicolumn{3}{|c|}{ Area } \\
\hline $\begin{array}{l}\text { square } \\
\text { inches }\end{array}$ & 6.4516 & $\begin{array}{l}\text { square } \\
\text { centimeters }\end{array}$ & $\begin{array}{l}\text { square } \\
\text { centimeters }\end{array}$ & 0.155 & $\begin{array}{l}\text { square } \\
\text { inches }\end{array}$ \\
\hline square feet & 0.092 & $\begin{array}{l}\text { square } \\
\text { meters }\end{array}$ & $\begin{array}{l}\text { square } \\
\text { meters }\end{array}$ & 10.7639 & $\begin{array}{l}\text { square } \\
\text { feet }\end{array}$ \\
\hline $\begin{array}{l}\text { square } \\
\text { yards }\end{array}$ & 0.836 & $\begin{array}{l}\text { square } \\
\text { meters }\end{array}$ & $\begin{array}{l}\text { square } \\
\text { meters }\end{array}$ & 1.20 & $\begin{array}{l}\text { square } \\
\text { yards }\end{array}$ \\
\hline $\begin{array}{l}\text { square } \\
\text { miles }\end{array}$ & 2.59 & $\begin{array}{l}\text { square } \\
\text { kilometers }\end{array}$ & $\begin{array}{l}\text { square } \\
\text { kilometers }\end{array}$ & 0.39 & $\begin{array}{l}\text { square } \\
\text { miles }\end{array}$ \\
\hline acres & $0 . \overline{404}$ & hectares & hectares & 2.471 & acres \\
\hline \multicolumn{3}{|c|}{ Mass (weight) } & \multicolumn{3}{|c|}{ Mass (weight) } \\
\hline ounces & 28.35 & grams & grams & 0.0352 & ounces \\
\hline pounds & 0.453 & kjlograms & kilograms & 2.2046 & pounds \\
\hline short ton & 0.907 & metric ton & metric ton & 1.10 & short ton \\
\hline \multicolumn{3}{|c|}{ Vol ume } & \multicolumn{3}{|c|}{ Volume } \\
\hline $\begin{array}{l}\text { fluid } \\
\text { ounces }\end{array}$ & 29.57 & milliliters & milliliters & 0.03 & $\begin{array}{l}\text { fluid } \\
\text { ounces }\end{array}$ \\
\hline quarts & 0.95 & Titers & 7iters & 1.057 & quarts \\
\hline gallons & 3.79 & liters & Titers & 0.26 & gallons \\
\hline cubic feet & 0.03 & $\begin{array}{l}\text { cubic } \\
\text { meters }\end{array}$ & $\begin{array}{l}\text { cubic } \\
\text { meters }\end{array}$ & 35.3147 & cubic feet \\
\hline cubic yards & 0.76456 & $\begin{array}{l}\text { cubic } \\
\text { meters }\end{array}$ & $\begin{array}{l}\text { cubic } \\
\text { meters }\end{array}$ & 1.308 & $\begin{array}{l}\text { cubic } \\
\text { yards }\end{array}$ \\
\hline \multicolumn{3}{|c|}{ Temperature } & \multicolumn{3}{|c|}{ Temperature } \\
\hline Fahrenhejt & $\begin{array}{l}\text { subtract } \\
32 \text { then } \\
\text { multiply } \\
\text { by } 5 / 9 \text { ths }\end{array}$ & Celsius & Celsius & $\begin{array}{l}\text { multiply } \\
\text { by } \\
9 / 5 \text { ths, } \\
\text { then add } \\
32\end{array}$ & Fahrenheit \\
\hline \multicolumn{3}{|c|}{ Force } & \multicolumn{3}{|c|}{ Force } \\
\hline $\begin{array}{l}\text { pounds per } \\
\text { square inch }\end{array}$ & 6.895 & kilopascals & kilopascals & $\begin{array}{l}1.4504 \times \\
10^{-4}\end{array}$ & $\begin{array}{l}\text { pounds per } \\
\text { square } \\
\text { inch }\end{array}$ \\
\hline
\end{tabular}

Source: Engineering Unit Conversions, M. R. Lindeburg, PE., Second Ed., 1990, Professional Publications, Inc., Belmont, California. 
HNF-EP-0468-4

\subsection{INTRODUCTION}

The U.S. Department of Energy (DOE) Order 5400.1 requires that a facility effluent monitoring plan (FEMP) be prepared for each DOE facility that has gaseous and/or liquid effluents. Only effluents that release significant pollutants or hazardous materials are included in this order; sanitary sewers and exhausts from air heating or cooling equipment are exempt.

The Plutonium-Uranium Extraction (PUREX) Plant, a collection of buildings and structures located in the 200 East Area of the Hanford Site, is transitioning into a surveillance and maintenance (S\&M) mode. When deactivation is completed, the PUREX Plant will be left unoccupied and locked, with periodic entry and surveillance, pending eventual decontamination and decommissioning. Only one air exhaust stack is active. Eleven air exhaust stacks, six wall exhausters, and previous waste water discharges have been eliminated.

\subsection{POLICY}

It is the policy of DOE and DOE contractors to conduct effluent monitoring that is adequate to determine whether human health and the environment are protected adequately during DOE operations and to determine whether operations are in compliance with DOE and other applicable federal, state, and local radioactive and nonradioactive hazardous materials standards and requirements. It is also the policy of DOE and DOE contractors to ensure that effluent monitoring programs meet high standards of quality and credibility.

\subsection{PURPOSE}

DOE Order 5400.1 requires each site, facility, or process that uses, generates, releases, or manages significant pollutants or radioactive or hazardous materials that could affect public and employee safety and the environment to have a FEMP. This document is specifically intended to meet this requirement for the PUREX PIant on the Hanford Site.

The purpose of the FEMP is to assess and document information used to determine if the monitoring, sampling, and controls are sufficient to protect the public and the environment and to assess whether these systems are in compliance with all federal, state, and local requirements and regulations. This FEMP is considered a subset of the Environmental Monitoring Plan (EMP) for the Hanford Site (DOE/RL-91-50, Rev 1).

\subsection{SCOPE}

This document includes program plans for monitoring and characterizing radioactive and nonradioactive hazardous materials discharged in DOE facility effluents. Also included is complete documentation for gaseous effluent monitoring systems for both radioactive and nonradioactive hazardous pollutants that could be discharged under routine and/or upset conditions. 
The scope of this document is as follows:

Section

2.0

3.0

4.0

5.0

6.0

7.0

8.0

9.0

10.0

11.0

12.0

13.0

14.0

15.0

16.0
Scope

This brief facility description summarizes the processes that produced the effluents and couples the processes with a listing of effluents.

DOE orders and federal and state regulations that estab] ish FEMP requirements, as well as discharge criteria, are provided.

Each gaseous and Tiquid effluent is characterized. Routine and upset conditions are described. The discharge criteria are developed and listed.

A description of each effluent's discharge point is provided.

The design criteria for the monitoring/sampling (M/S) system are listed for both air and water effluents.

Instrument descriptions and specifications of the eff]uent monitoring system are provided.

Appropriate historical $\mathrm{M} / \mathrm{S}$ data are summarized.

AnaTytical requirements are referenced along with sampling and sample handling procedures.

Notification and reporting requirements for routine and environmental occurrence reports and procedural changes are referenced.

Interface of the FEMP with the near-facility environmental monitoring program is provided.

A quality assurance (QA) plan governing the field activities, Taboratory analysis, and recordkeeping is stated.

Internal and external FEMP review requirements are provided.

Compliance assessment is summarized. A point-by-point evaluation of the National Emission Standards for Hazardous Air Pollutants (NESHAPs) is referenced.

A summary is provided and conclusions are listed.

References.

\subsection{DISCUSSION}

The characterization of the radioactive and nonradioactive constituents in each effluent stream coupled to the regulatory framework provides the underlying rationale for the $\mathrm{M} / \mathrm{S}$ programs. The method of characterization discussed in this plan identifies potential pollutants in their individual 
effluents. Characterization parameters are based on process knowledge and chemical and equipment use. An accurate description of the effluents point of discharge is required for emission modeling and location of end-of-the-pipe M/S stations. Both normal and upset conditions (either projected or actual) are characterized.

As stated in 40 Code of Federal Regulations (CFR) 61 , Subpart $H$, when determining the potential dose from an effluent, the emission controls between the point of generation and the discharge point are not to be considered. The emission controls are to be considered when assessing the types and amounts of a pollutant actually released at the discharge point.

The effluent monitoring system has the appropriate design criteria and technical specifications to fully characterize the effluent streams. A combination of continuous sensing, continuous or periodic sampling, and parameter-specific monitoring are used per the requirements of the Environmenta7 Regulatory Guide for Radiological Effluent Monitoring and Environmenta7 Surveillance (DOE/EH-0173T) and 40 CFR 61, subpart H.

Proper sampling, analysis, and data recording of all effluent monitoring efforts provide defensible documentation that all appropriate discharge criteria are being met at the point of discharge. 
HNF-EP-0468-4

This page intentionally left blank. 
HNF-EP-0468-4

\subsection{FACILITY DESCRIPTION}

This chapter presents a brief facility and process description of the PUREX Plant. These descriptions include the following:

- Location and physical layout of the process facility

- General description of the present, past, and future activities of the process

- Identity of the waste streams.

Chapter 4.0, provides further specific information on the gaseous and liquid effluents.

\subsection{BRIEF FACILITY PHYSICAL LAYOUT}

The PUREX Plant is a collection of buildings and structures located in the 200 East Area of the Hanford Site, which is located in Washington State (Figure 2-1). Figure 2-2 is a plot plan for the PUREX Plant. The main building, 202-A (Figure 2-3), is a heavily shielded, reinforced-concrete structure known as a canyon building. The 202-A Building contains the main equipment used in the PUREX process. Buildings and structures that have the greatest connection to gaseous and Tiquid effiuents are described in the following sections.

\section{1 .1 202-A Building}

The 202-A Building, in which the fuels were reprocessed, is a reinforcedconcrete structure 306 meters long, 36 meters wide at its maximum, and 30 meters high, with about 12 meters of this height below grade. The 202-A Building consists of three main structural components: (1) a thick-walled, concrete canyon in which the equipment for radioactive processing is contained; (2) the pipe and operating ( $P \& 0)$, sample, and storage galleries; and (3) a steel-and-transite annex for offices, process control rooms, laboratories, and building services. The basic features and arrangement are shown by the cut-away perspective view in Figure 2-3. The portion of the canyon below grade is subdivided into a row of process equipment cells paralleled by a ventilation air tunnel and a pipe tunnel through which intercell solution transfers were made. The air tunnel exhausted the ventilation air from the cells to the main ventilation filters and stack.

Running nearly the full length of the canyon building, above the cells and pipe trench, is a craneway for three gantry-type maintenance cranes. These cranes were used to handle cell cover blocks, remotely remove and replace process cell equipment, and charge irradiated fuel into the dissolvers.

The galleries contained service piping to the cells, samplers for obtaining process samples, and electrical switchgear. 
The service section, next to the galleries, consisted of two separate annexes. The larger annex contained the maintenance shops, offices, lunchroom, locker room, radiation zone entry lobby, blower room, a switchgear room, compressor room, central control room, and the aqueous makeup unit area. The smaller annex contained the analytical laboratory, the headend control room, and a switchgear room.

\subsubsection{Effluent Monitoring Building}

The 292-AB Building houses $M / S$ equipment for the one remaining gaseous effluent stream. A sampling and monitoring control system (SAMCONS) is linked remotely to the 271-U Building in the 200. West Area. The SAMCONS unit monitors the differential pressure (DP) at various locations within the canyon building, the DP across the deep bed and high-efficiency particulate air (HEPA) filters, the status of the exhaust fans, and other parameters to ensure that the monitoring system is functioning properly. Operation of the PUREX SAMCONS is addressed in plant operating procedures, which are maintained onsite. When the facility is turned over to Bechtel Hanford, Inc. (BHI), the Environmental Restoration Contractor, the procedures will be addressed by BHI field support procedures.

\subsubsection{RaiTroad Tunnel and Storage Tunnels}

The railroad tunnel received irradiated fuel and large pieces of equipment transported to PUREX via railcars. The railroad tunnel enters the north side of the east end of the 202-A Building, continues through the building, and exits on the south side of the building, connecting to the storage tunnels. The storage tunnels are two parallel, earth-covered tunnels that contain railroad tracks. The storage tunnels are isolated from the railroad tunnel by water fillable doors. The tunnels contain failed equipment (loaded on railroad cars) contaminated with high levels of radioactivity or jtems too bulky for immediate burial. Storage of the equipment allows the radioactivity to decay to lower levels.

\section{1 .4 291-AE Building}

The 291-AE Building is an above grade concrete structure housing the No. 4 HEPA filter system. The No. 4 filter system consists of 10 parallel banks of two-stage HEPA filters for final filtration of the canyon exhaust system. Instrumentation to detect pressure drop across each stage and gamma radiation at the first stage is part of the filter system.

\subsection{BRIEF PROCESS DESCRIPTION}

The PUREX Plant separated useable actinides from fission products in irradiated nuclear fuel. The process consisted of dissolving the fuel and separating the actinides using liquid-liquid solvent extraction. The driving forces for the separations consist of concentration changes, temperature changes, and chemical additions. The PUREX Plant had been the source of five liquid effluent streams, which were mostly by-products of the chemical separation processes. These liquid effluent streams were the chemical sewer, 
the steam condensate, the process distillate discharge, the ammonia scrubber discharge, and the cooling water streams. The PUREX Plant had been the source of 11 principal gaseous effluent streams that resulted from the control of process vapors/gases and potential contamination. of the 12 PUREX stacks, only 1 is active. Continuous air flow through the process areas ensures control of trace quantities of contamination. The five liquid effluent streams have been eliminated.

\subsection{PRESENT AND FUTURE ACTIVITIES}

The PUREX PIant has completed transition activities to shutdown and has been $p l a c e d$ in a safe and environmentally secure configuration. The four ventilation systems have been consolidated into one by cascading air from one ventilation system to another. This has reduced the volume of air discharged and the number of stack monitoring stations needed following deactivation. Final discharge of all air will be through the main stack via the canyon.

The PUREX Storage Tunnel Number 2 has room for additional waste storage. Future additions to the tunnel would require approval from the Washington State Department of Health (WDOH), and would require upgrades to the existing exhaust system.

\subsection{IDENTIFICATION/CHARACTERIZATION OF POTENTIAL SOURCE TERMS}

Potential source terms for effiuents from the PUREX PIant have been minimized through deactivation efforts. Residual contamination is still present in various locations. However, contamination is static now that the plant is in S\&M. This document has been written to address the current S\&M. status of the PUREX Plant.

\subsubsection{Gaseous Effluents}

The contributors to a gaseous effluent are linked by physical location and are not related to a specific process. The PUREX Plant has only one discharge point remaining with the potential to release radioactive constituents, the PUREX main exhaust stack (291-A-1).

The PUREX Storage Tunnel Number 2 (296-A-10) currently is inactive. Future waste additions to the tunnel would require reactivation and upgrades to this stack.

\subsubsection{Liquid Effluents}

The majority of liquids have been removed from the PUREX Plant, with only residual amounts (heels) remaining; however, there is no longer a potential for Tiquid releases. Storm water is not controlled, but is allowed to evaporate in place or infiltrate into the ground. Residual contamination has been removed or fixed in place, so contact with storm water poses no threat of release. 
HNF-EP-0468-4

This page intentionally left blank. 


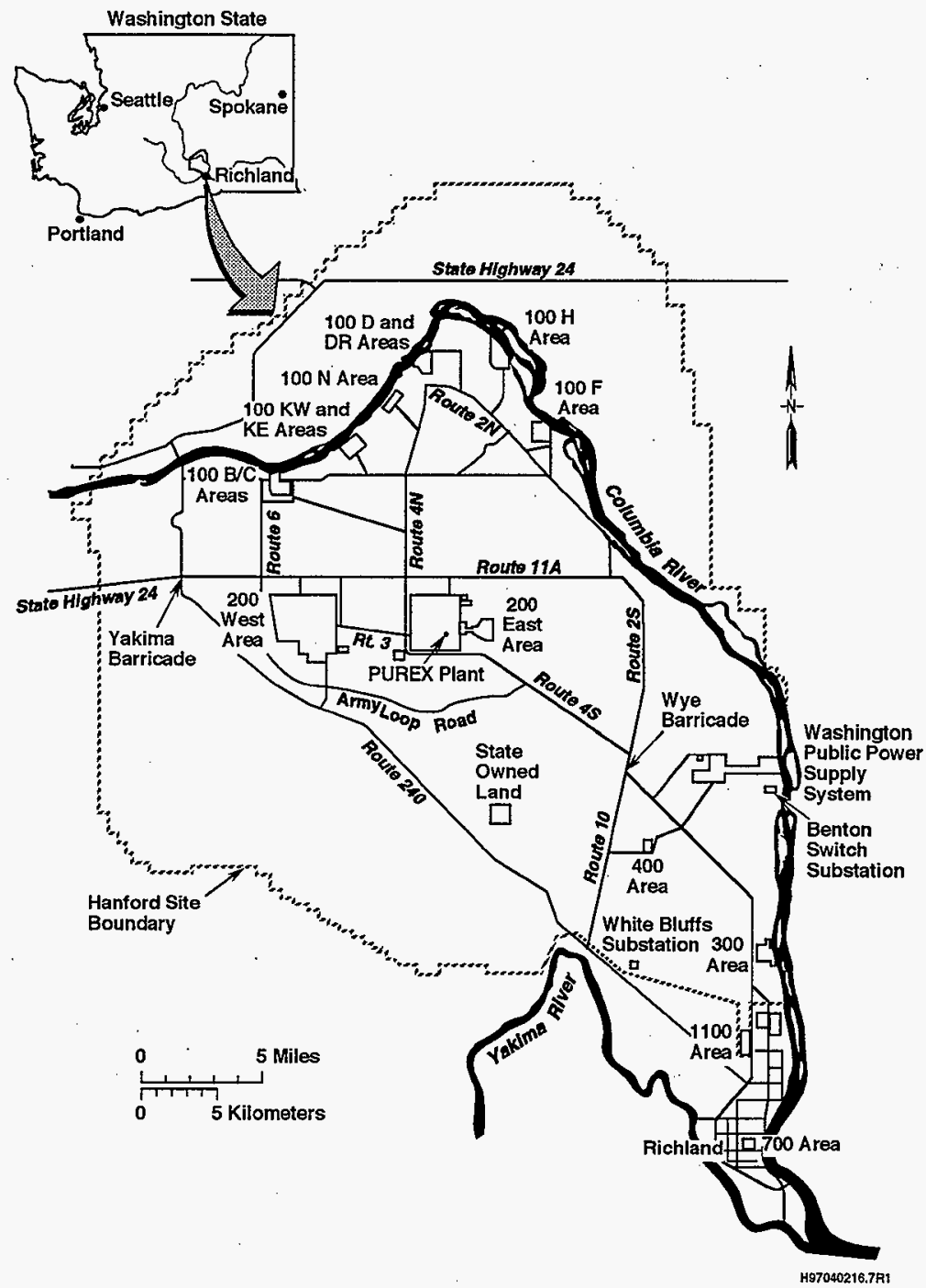

Figure 2-1. Location of the Plutonium-Uranium Extraction Plant. 


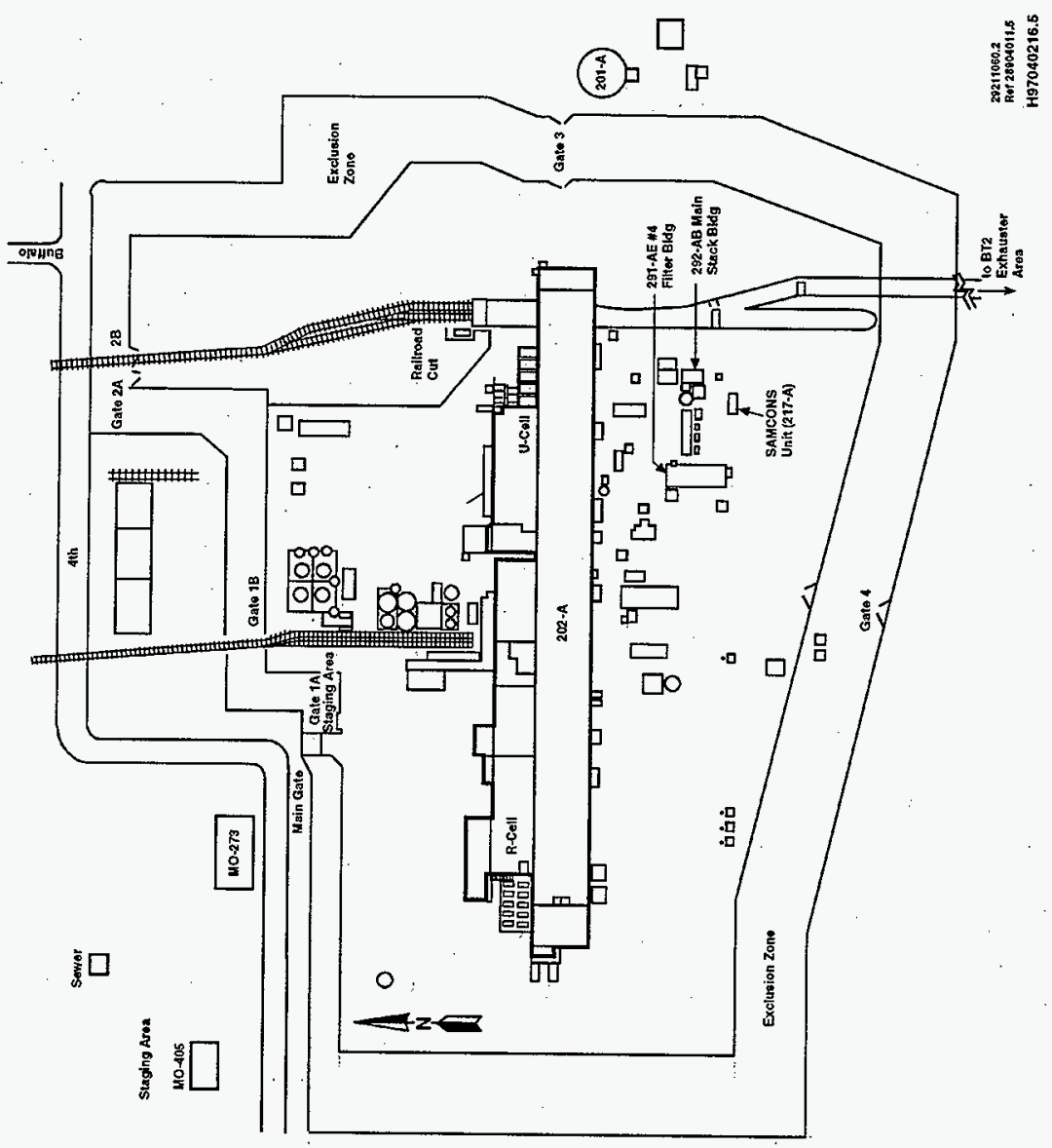

Figure 2-2. PTutonium-Uranium Extraction Plant Plot PTan. 

HNF-EP-0468-4

This page intentionally left blank. 


\subsection{APPLICABLE REGULATIONS}

Conditions and requirements for monitoring existing or potential releases of radioactivity and other chemicals to the environment are contained in DOE Orders and federal, state, and local laws and regulations. A brief summary of the regulations and standards applicable to this FEMP follows.

\subsection{U.S. DEPARTMENT OF ENERGY ORDERS}

DOE Order 5400.1 requires a written environmental monitoring $\mathrm{p} 1$ an for each site, facility, or process that uses, generates, releases, or manages significant pollutants or hazardous materials. The plan must include the rationale and design criteria for the monitoring program, as well as describe the extent and frequency of the monitoring analysis. The plan also must contain quality assurance (QA) requirements, program implementation procedures, directions for preparation and implementation of reports, and directions for identification and discussion of effluent monitoring and environmental surveillance.

The effluent monitoring portion of the plan must verify compliance with applicable regulations and DOE Orders. The plan also should evaluate the effectiveness of treatment; identify potential environmental problems; evaluate the need for remedial action or mitigation measures; support permit revision and/or reissuance; and detect, characterize, and report unplanned releases.

DOE Order 5400.5 requires a monitoring $p 1$ an that complies with the requirements of DOE Order 5400.1 . Compliance with the requirements of DOE Order 5400.5 can be demonstrated based on calculations from monitoring and surveillance programs.

\subsection{FEDERAL REGULATIONS}

Applicable federal regulations are discussed in the following sections.

\subsubsection{Environmental Protection Agency Regulations on National Emission Standards for Hazardous Air Pollutants 40 CFR 61}

Subpart $H$ of 40 CFR 61 establishes exposure limits and monitoring requirements. The exposure limits for members of the public from radionuclide emissions is an effective dose equivalent (EDE) not to exceed $10 \mathrm{millirem} /$ year. Compliance with this standard is measured by calculating the highest EDE where a person resides or abides using an EPA-approved method.

Emissions are measured at alf release points that have a potential to discharge radionuclides into the air in quantities that could cause an EDE in excess of 1 percent of the standard. Effluent streams are monitored continuously with an in-line detector or representative samples of the effluent stream are withdrawn continuously from the sampling site following the guidance presented in American National Standards Institute (ANSI) N13.1. The requirements for continuous sampling are applicable to batch processes 


$$
\text { HNF-EP-0468-4 }
$$

when the unit is in operation. Periodic sampling (grab samples) can be used only with EPA's approval, e.g., if the stack is redesignated as a minor emission point. Such approval could be granted in cases where continuous sampling is not practical and radionuclide emission rates are relatively constant. In such cases, grab samples are collected with sufficient frequency to provide a representative sample of the emissions.

To determine whether a release point is subject to emission measurement requirements, it is necessary to evaluate the potential for radionuclide emissions for that release point. In evaluating the potential of a release point to discharge radionuclides into the air, the estimated radionuclide release rates are based on the discharge of the effluent stream that would result if all pollution control equipment did not exist, but the facility operations were otherwise normal.

If the EDE caused by all emissions is less than 1 percent of the standard ( $<0.1$ millirem), the facility is exempt from the EPA monitoring requirements. All radionuclides that could contribute greater than 10 percent of the potential EDE for a release point are measured individually, as discussed in the statement of work for the Effluent and Environmental Monitoring (EEM) Program for services provided by the Waste Sampling and Characterization Facility (WSCF) (HNF 1997). With prior EPA approval, DOE could determine these emissions through alternative procedures. For other release points that have a potential to release radionuclides into the air, periodic confirmatory measurements will be made to verify low emissions.

\subsubsection{Reportable Quantities 40 CFR 302}

The regulations in 40 CFR 302 designate hazardous substances and identify reportable quantities and notification requirements for releases of these hazardous substances under the Comprehensive Environmental Response, Compensation, and Liability Act (CERCLA) of 1980, as amended.

Any unpermitted release of any of these designated hazardous substances must be reported. There is virtually no possibility to release any of the designated substances at the PUREX Plant.

\subsection{STATE REgULATIONS}

Applicable state regulations are discussed in the following sections.

\subsubsection{Washington State Ambient Air Quality Standard and Emission Limits for Radionucl ides WAC-173-480}

Although the standard for Washington State establishes a 25 millirem per year EDE for public exposure to radionuclide emissions, facilities must comply with the most restrictive federa1, state, or local 1aw. Therefore, the exposure limit that must be complied with is 10 millirem per year (NESHAPs); however, compliance is calculated at the point of maximum annual air concentration in an unrestricted area where any member of the public might be located (fence boundary). 
HNF-EP-0468-4

\subsubsection{Groundwater Protection}

There are no applicable requirements for groundwater protection.

\subsubsection{Dangerous Waste Regulations}

A] though most dangerous wastes have been removed from the PUREX P1ant, Dangerous Waste Regulations, Washington Administrative Code (WAC) 173-303 will remain applicable to the PUREX Plant until final closure is accomplished per applicable regulatory provisions and agreements.

\subsection{LOCAL REGULATIONS}

The Benton County Air Pollution Control Authority only has jurisdiction on the Hanford Site over asbestos and open burning. Currently, there are no local standards more restrictive than the previousiy mentioned federal and state limits. Therefore, federal and state standards apply.

\subsection{AIR EMISSIONS}

DOE Order 5400.5 provides requirements for the monitoring of radioactive and nonradioactive airborne effluents from DOE facilities. This Order states that DOE-controlled facilities must comply with 40 CFR 61 .

In Washington State, airborne effluents are regulated by the Washington State Department of Ecology (Ecology) through regulations in the WAC, Chapters 173-400 through 173-490, as amended, pursuant to the Washington Clean Air Act (RCW, Title 70, Public Health and Safety Chapter 94, as amended). General regulations for air pollution sources are presented in WAC 173-400, including emission standards for sources emitting hazardous air pollutants found in WAC 173-400-075.

The WAC 246-247, Radiation Protection Air Emissions, specifies new source review, notification, registration, and permitting requirements associated with any source of radioactive air emissions in Washington State, including those on the Hanford Site. One requirement listed in WAC 246-247 is the semiannual (twice yearly) reporting of emissions from each registered stack or vent onsite. By agreement with the $\mathrm{WDOH}$, only annual reporting is required.

In Washington State, airborne effluents are regulated by the Washington Clean Air Act of 1967. General regulations for air pollution sources are presented in WAC 173 400, including emission standards for sources emitting hazardous air pollutants in WAC 173-400-075. New sources for toxic air pollutants are presented in WAC 173-460. State regulations pertaining specifically to radioactive airborne effluents are found in WAC 246-247 and WAC 173-480, and are more restrictive in most cases than the federal requirements.

Regulations, including DOE Orders, state that DOE facilities must comply with the requirements set forth in NESHAP. Other regulations (e.g., 40 CFR 52 


\section{HNF-EP-0468-4}

and DOE Orders $5400.1,5400.5$, and 5484.1) state that DOE facilities must comply with the applicable requirements set forth in the Clean Air Act.

\subsection{LIQUID EFFLUENTS}

There are no liquid effluents remaining at PUREX. 
HNF-EP-0468-4

\subsection{IDENTIFICATION/CHARACTERIZATION OF EFFLUENT STREAMS}

This chapter addresses the chemical and radiological composition of PUREX effluents. A description of the gaseous effluents is followed by a brief discussion of routine and upset operating conditions.

\subsection{IDENTIFICATION/CHARACTERIZATION OF SOURCE TERMS CONTRIBUTION TO EACH AIR EFFLUENT STREAM}

The PUREX PIant had 10 sources of major air effluent streams with a potential for contamination during the transition to shutdown mode.

Characterization of the effluents is based on 1996 concentration and flow data and these are representative of standby or transition to shutdown conditions. The characterizations that follow are taken from the Effluent Monitoring Plan PUREX Gaseous Eff7uents (WHC-SD-CP-EMP-004).

\section{1-A-1 - Main Building Exhaust Stack}

The point of discharge is a 61-meter tall stack, located south of the 202-A Building. In 1996, the typical flow rate was between 28 and 58 cubic meters/second, the average flow rate was 45 cubic meters/second. In 1996, the exhaust contained on the average 1.1 E-12 microcuries/milliliter radioactivity. During the S\&M mode, flow rates typically will be 19 cubic meters per second.

\section{6-A-10 - Storage Tunnel No. 2 Exhaust}

The 296-A-10 Stack, located about 640 meters south of the 202-A Building, is 6 meters high. The powered exhaust/ventilation system associated with the 296-A-10 stack was shut down on December 23, 1996. The 296-A-10 stack was a minor stack, exhausting filtered air from the PUREX Storage Tunnel Number 2. With concurrence from $W D O H$, the stack was shut down. The stack was de-energized and a cap was placed on the stack. Because of the low loading on the HEPA filters, it was not necessary to remove the filters. With the understanding that future waste additions to the tunnel would require an upgrade to the stack, conditions were left so that an upgrade is still an option. The HEPA filters were left in place. The flex joint downstream of the fan housing (between the housing and the stack) was blanked with solid blanks. A metal band was placed on the flex joint between the tunnel and the exhaust fan, and sealed with a sealant. This weather-proofed the joint, and serves as an alternative to blanking. These activities were completed on February 26, 1997.

\subsubsection{Routine Operations}

The ventilation systems will continue to exhaust the same areas of the PUREX Plant as described in Chapter 2.0. However, because the PUREX Plant has been shutdown (i.e., no processing), the source radionuclides that might be vented have been reduced, and the effluent concentrations are expected to continue to decrease during the S\&M mode. 
HNF-EP-0468-4

\subsubsection{Upset Operating Conditions}

The Effluent Monitoring P7an for PUREX Gaseous Effluents (WHC-SD-CP-EMP-004) described upset conditions for each stack. However, these conditions were based on the PUREX process being active and therefore are no longer applicable. In the shutdown mode, upset operating conditions could involve failure of a single engineered barrier, which is taken to be a failure of the HEPA filtration. A HEPA filter failure is modeled in Section 4.1.3.2.

\subsubsection{Dispersion Modeling}

Only radiological emissions are present in the PUREX PIant air effluent during the shutdown mode. The CAP- 88 computer code calculates EDE that result from the air transport of radionuclides released from the effluent discharge points above the PUREX PT ant (WHC-EP-0498).

The CAP-88 code is approved by the EPA for demonstrating compliance with the NESHAPs standard for radiological releases. CAP-88 computes the radiation exposure to the Hanford Sites' maximally exposed individual (MEI), or the nearest receptor from a particular facility, via the ingestion, inhalation, air-immersion (exposure resuiting from being inside plume of radiation), and groundshine (exposure resulting from deposited radioactive particles) pathways. CAP-88 incorporates dose conversion factors from the International Commission on Radiological Protection (ICRP) 26/30 methodology. Resulting doses are a 50-year committed EDE. The magnitude of exposure via any of the pathways is related strongly to the distance between the source and receptor.

CAP-88 uses a Gaussian plume methodology for dispersing air contaminants to downwind Tocations. Because of the low temperatures of the PUREX Plant stacks, CAP-88 calculates plume rise solely from stack exhaust momentum. During transport, the plume undergoes a reduction in air concentration, not only through dispersion, but also from plume depletion processes.

These processes include radioactive decay, precipitation, scavenging, and dry deposition. Because of the long half-lives of the radionuclides released and the relatively dry climate in eastern Washington State, only the dry deposition removal process has an appreciable effect on the resulting downwind air concentration.

Stack characteristics, including stack height above the ground, stack diameter, and exhaust velocity or flow rate, are used to assess the plume rise and determine the final height of release of the plume. Air effluents are released at room temperature; as such, plume rises are not thermally driven. Table 4-1 summarizes the characteristics of the active PUREX Plant exhaust stack.

The emission points used for modeling purposes are centered on each of the major Hanford Site operating areas that release radionuclides to the atmosphere. For the PUREX P1 ant, located in the 200 East Area, the reference point was the meteorology tower located approximately midway between the 200 East and 200 West Areas. This Tocation was chosen to represent emissions from the 200 Areas because the tower lies between two major groups of facilities that account for the bulk of stack releases. A farm at Ringold, 
Washington, was determined to be the best location to use in the compliance analysis. Table 4-2 in WHC-EP-0498 shows the 200 East Area unit dose conversion factors for the offsite hypothetical MEI used to calculate the EDE.

4.1.3.1 Routine Release Dose Assessment. During S\&M activities at the PUREX Plant, only small quantities of radionucilides are released from the exhaust stack (Tables 4-3). The MEI used for the Hanford Site dose calculations is located approximately 16 kilometers east of the PUREX P1ant, based on a hypothetical release point at the Hanford Meteorology Station.

An EDE of 0.0007 millirem was assessed for the MEI location as a result of releases from PUREX Plant stacks that operated in 1996. This total dose is well below the EPA annual dose criterion in 40 CFR 61 of 10 millirem to the MEI via the air pathway. This total dose is intended to be used for total-facility, emission-compliance purposes but not for monitoring requirements. Any stack with an individual potential dose greater than the EPA standard of 0.1 millirem per year (1 percent of $10 \mathrm{millirem}$ per year) is required to have 'continuous radiation monitoring'. This continuous radiation monitoring is an EPA designation that is fully met by continuous sampling with periodic analysis.

The MEI dose resulted primarily from the ingestion and inhalation of iodine-129 that originated from the canyon exhaust stack (291-A-1).

\subsubsection{Upset Release Dose Assessment. Applicable EPA regulations in 40 CFR 61 require that a dose to the nearest receptor be calculated from an unmitigated release. An unmitigated release occurs in the case of an upset in which all air pollution control equipment fails (or is considered to have been removed). At the PUREX Plant, this means a dose that results from the unfiltered flow from the main stack effluent described in Table 4-3. Monitoring of the effluent stream is not made upstream of the HEPA filters. Consequently, the increase in effluent radionuclides due to filter removal is based on an evaluation of filter efficiencies and the particulate removal processes.}

The 291-A-1 stack (the main stack) exhausts through three stages of HEPA filters. A conservative increase in particulate effluent due to filter removal is $(3000.0)^{n}$ for the main stack, where $n$ is the number of HEPA filter stages.

The iodine emission control equipment (the silver reactors of the dissolver offgas system) was neither needed nor in service during the transition to shutdown. Because there is no increase in radioactive iodine emissions due to bypass of pollution control equipment, the unmitigated release factor is 1.0 .

The dose calculated for the MEI is directly proportional to the amount of radioactive material released. Because all particulate releases are increased by the same amount in a given stack, the resulting unmitigated dose is the MEI dose increased by a unmitigated release factor of $(3000)^{3}$ for particulates and 1.0 for volatiles.

Table 4-4 summarizes the contributions to the unmitigated MEI dose from the PUREX Plant main stack during transition to shutdown. Any stack with an individual annual dose greater than the EPA standard of 0.1 millirem per year 
is required to have a minimum of continuous sampling and subsequent analysis. The main stack has potential unmitigated dose consequences that are in excess. of this standard.

The unmitigated MEI dose would result primarily from the ingestion and inhalation of americium-241 and plutonium-239/240 originating from the main stack at the PUREX Plant. Table 4-5 summarizes the most significant radionuclides and their dose contributions to the MEI. Any radionuclide that contributes 10 percent of the dose from a release point that could exceed the EPA annual dose standard of 0.1 millirem must be measured. Two radionuclides from the main stack (americium-241 and plutonium-239/240) exceed this standard and will require measurement. Air monitoring requirements are discussed in more detail in Chapter 7.0, Section 7.1.

\subsection{IDENTIFICATION/CHARACTERIZATION OF SOURCE TERMS CONTRIBUTING TO EACH LIQUID EFFLUENT STREAM}

There are no liquid effluent streams remaining at the PUREX PTant. 
Table 4-1. Plutonium-Uranium Extraction Plants Stack Exhaust Data.

\begin{tabular}{|l|c|c|c|c|c|}
\hline \multirow{2}{*}{$\begin{array}{c}\text { Stack } \\
\text { reference }\end{array}$} & Height & $\begin{array}{c}\text { Stack } \\
\text { diameter }\end{array}$ & $\begin{array}{c}\text { Out let } \\
\text { diameter }\end{array}$ & $\begin{array}{c}\text { Average } \\
\text { flow* }\end{array}$ & Temperature \\
\cline { 2 - 6 } & $(\mathrm{m})$ & $(\mathrm{m})$ & $(\mathrm{m})$ & $\left(\mathrm{m}^{3} / \mathrm{s}\right)$ & $\left({ }^{\circ} \mathrm{C}\right)$ \\
\hline $291-\mathrm{A}-1$ & 61.0 & 2.13 & 2.13 & 18.71 & ambient \\
\hline $296-\mathrm{A}-10$ & 6.1 & 0.71 & 0.71 & 0.00 & ambient \\
\hline
\end{tabular}

* Average flow in S\&M mode.

Table 4-2. CAP-88 Unit Dose Factors for the Nearest Receptor Affected by Radionuclide Air Emissions from PUREX (200 East Area)*

\begin{tabular}{|l|c|}
\hline \multicolumn{1}{|c|}{ Release Location } & 200 East Area \\
\hline Release Height & 89 meters \\
\hline Rearest Receptor & 16 kilometers east \\
\hline \hline${ }^{90} \mathrm{Sr}$ & $\begin{array}{c}\text { Effective Dose Equivalent } \\
\text { (millirem per curie year) }\end{array}$ \\
\hline${ }^{125} \mathrm{Sb}$ & $1.20 \mathrm{E}-02$ \\
\hline${ }^{129} \mathrm{I}$ & $1.14 \mathrm{E}-03$ \\
\hline${ }^{137} \mathrm{Cs}$ & $1.84 \mathrm{E}-01$ \\
\hline${ }^{238} \mathrm{Pu}$ & $6.54 \mathrm{E}-03$ \\
\hline${ }^{239,}{ }^{240} \mathrm{Pu}$ & $2.19 \mathrm{E}+00$ \\
\hline${ }^{241} \mathrm{Pu}$ & $2.37 \mathrm{E}+00$ \\
\hline${ }^{241} \mathrm{Am}$ & $3.76 \mathrm{E}-02$ \\
\hline
\end{tabular}

* Source: WHC-EP-0498. 
Table 4-3. Individual Radionuclide Doses to Maximally Exposed Individual for 1996 from 291-A-1.

\begin{tabular}{|l|c|c|}
\hline \multicolumn{1}{|c|}{ Radionuclide } & Release (curie) & $\begin{array}{c}\text { EDE } \\
\text { (millirem per year) }\end{array}$ \\
\hline${ }^{90} \mathrm{Sr}$ & $2.4 \mathrm{E}-05$ & $2.9 \mathrm{E}-07$ \\
\hline${ }^{125} \mathrm{Sb}$ & $1.9 \mathrm{E}-06$ & $2.2 \mathrm{E}-09$ \\
\hline${ }^{129} \mathrm{I}$ & $3.6 \mathrm{E}-03$ & $6.6 \mathrm{E}-04$ \\
\hline${ }^{137} \mathrm{Cs}$ & $7.9 \mathrm{E}-05$ & $5.2 \mathrm{E}-07$ \\
\hline${ }^{238} \mathrm{Pu}$ & $1.7 \mathrm{E}-07$ & $3.7 \mathrm{E}-07$ \\
\hline${ }^{239,}{ }^{240} \mathrm{Pu}$ & $2.8 \mathrm{E}-06$ & $6.6 \mathrm{E}-06$ \\
\hline${ }^{249} \mathrm{Pu}$ & $1.4 \mathrm{E}-05$ & $5.3 \mathrm{E}-07$ \\
\hline${ }^{241} \mathrm{Am}$ & $8.8 \mathrm{E}-06$ & $3.2 \mathrm{E}-05$ \\
\hline Total & & $7.0 \mathrm{E}-04$ \\
\hline
\end{tabular}

TabTe 4-4. Potential Doses to the Maxima11y Exposed Individual from an Unmitigated Release.

\begin{tabular}{|c|l|c|c|c|c|}
\hline \multicolumn{2}{|c|}{ Stack reference } & $\begin{array}{c}\text { Effective } \\
\text { dose } \\
\text { equivalent } \\
\text { (millirem) }\end{array}$ & $\begin{array}{c}\text { Unmitigated } \\
\text { release } \\
\text { factor } \\
(3000)^{n}\end{array}$ & $\begin{array}{c}\text { Unmitigated } \\
\text { effective } \\
\text { dose } \\
\text { equivalent } \\
\text { (millirem) }\end{array}$ & $\begin{array}{c}\text { Dose } \\
\text { standard } \\
\text { for required } \\
\text { monitoring } \\
\text { (millirem) }\end{array}$ \\
\hline \multirow{3}{*}{$291-\mathrm{A}-1$} & Volatiles & $6.6 \mathrm{E}-04$ & $(3000)^{0}$ & $6.6 \mathrm{E}-04$ & \\
\cline { 2 - 7 } & Particulates & $4.0 \mathrm{E}-05$ & $(3000)^{3}$ & $1.1 \mathrm{E}+06$ & \\
\cline { 2 - 7 } & Total & $7.0 \mathrm{E}-04$ & -- & $1.1 \mathrm{E}+06$ & $1.0 \mathrm{E}-01$ \\
\hline
\end{tabular}

* Dose standard for total radioactivity effluent monitoring from 40 CFR 61, Subpart $H$.

$n=$ number of HEPA filtration stages.

Tab7e 4-5. Potential Individual Radionuclije Doses to the Maximally Exposed Individual from an Unmitigated Release.

\begin{tabular}{|c|c|c|c|}
\hline PUREX stack & Radionuclide & $\begin{array}{c}\text { Effective dose } \\
\text { equivalent } \\
\text { contribution } \\
\text { (mil irem per year) }\end{array}$ & $\begin{array}{c}\text { Contribution to } \\
\text { stack total \% }\end{array}$ \\
\hline $291-\mathrm{A}-1$ & ${ }^{239,240} \mathrm{Pu}$ & $1.8 \mathrm{E}+05$ & 17 \\
\hline
\end{tabular}




\subsection{EFFLUENT POINT OF DISCHARGE DESCRIPTION}

This chapter describes the point of discharge for both the air and liquid effluents. Additional information on air and water effluents, and sampling systems and operations, are contained in Chapters 4.0 and 7.0.

\subsection{AIR EFFLUENTS}

The main stack, 291-A-1, is the only active air effluent stream. It's associated stack dimensions, flow velocities, and temperatures have been summarized in Chapter 4.0, Table 4-1. The 296-A-10 stack has been shut down and is currently inactive. The other 10 stacks that have shut down are the 296-A-1, 296-A-2, 296-A-3, 296-A-5A, 296-A-5B, 296-A-6, 296-A-7, 296-A-8, 296-A-14, and 296-A-24. Reports of closure for these stacks have been filed with WDOH. The Tocation of each stack is shown in Figure 5-1.

\subsection{WATER EFFLUENTS}

There are no remaining water effluents from the PUREX Plant. 
HNF-EP-0468-4

This page intentionally left blank. 


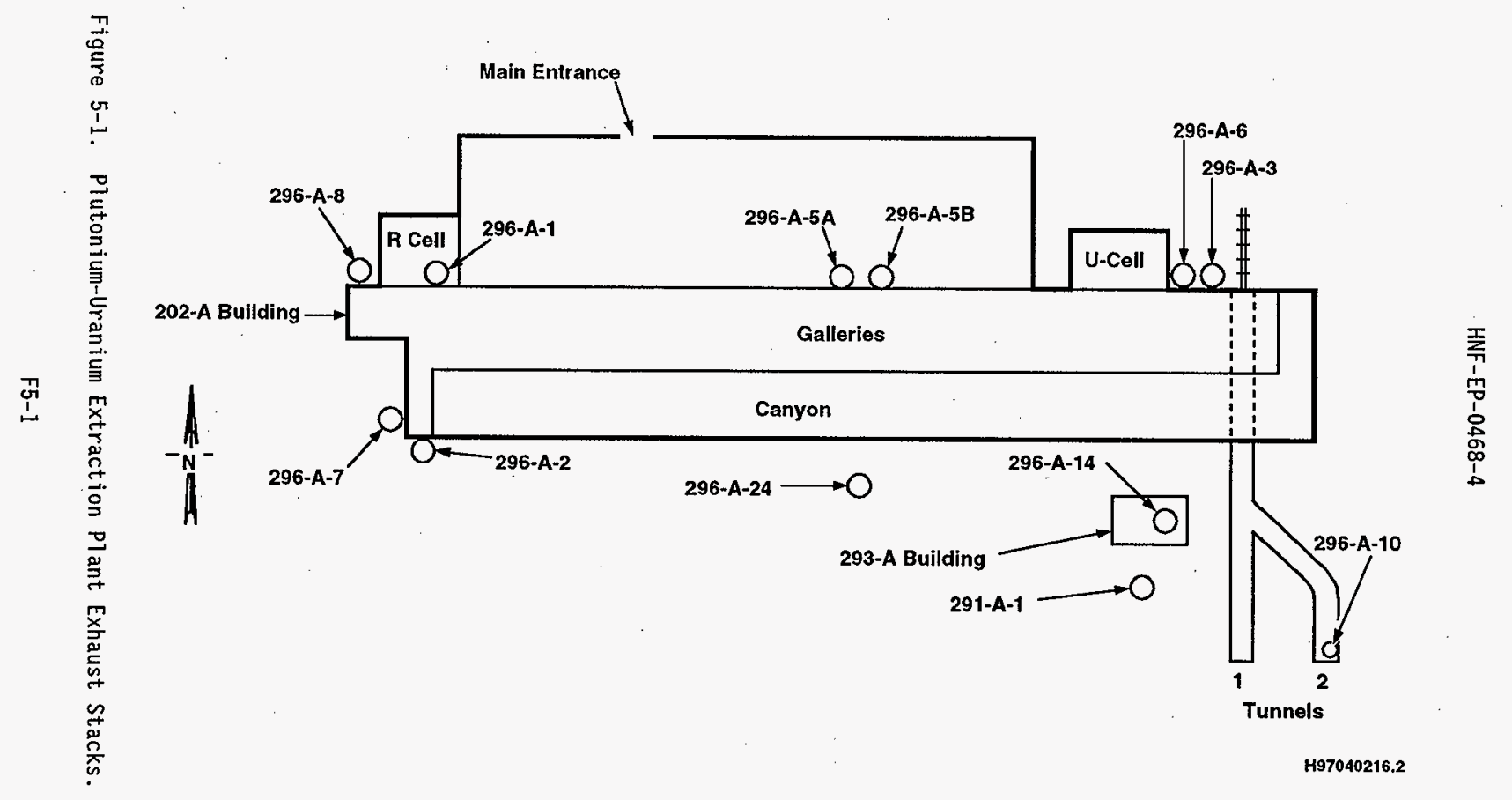


HNF-EP-0468-4

This page intentionally left blank.

F5-2 
HNF-EP-0468-4

\subsection{EFFLUENT MONITORING/SAMPLING SYSTEM DESIGN CRITERIA}

Airborne radionuclide concentration monitoring requirements at the PUREX Plant are met by sampling and analysis. The measurements are validated and formally reported to determine regulatory compliance.

\subsection{EXISTING FACILITIES}

The equipment used for the air monitor/sample systems for the PUREX Plant meets the following common design criteria: the equipment must be accurate, rugged, and low maintenance.

\subsection{AIRBORNE EFFLUENT SAMPLING AND MONITORING SYSTEM DESIGN CRITERIA}

Airborne effluent sampling is required of all gaseous release points with the potential to emit radionuclides from industrial sources. Additional specific criteria that apply to the air effluents are the requirements to accomplish the following:

- Sense pressure drop across the HEPA filters

- Take continuous air samples with isokinetic sampling probes, filter holders, and vacuum pumps

- Detect and alarm upon a loss of ventilation flow control.

Design criteria were developed for generic stack sampler/monitor systems to provide system design and operating capabilities as required in current DOE Orders and directives, ANSI guidelines, and NESHAP requirements.

The current equipment includes a stack effluent flow rate monitor with flow totalizing capability. The following features also are provided.

- The stack flow rate monitoring system has a flow rate sensing element located within the stack in a location that will not interfere with the effluent sample extraction probes. The flow rate transmitter provides an electrical signal that is proportional to the stack flow rate, thus controlling a flow rate indicator and totalizer.

- Flow probe sensing lines are protected from condensation of moisture.

- Periodic flow rate measurements are conducted to verify the automatic flow sensor measurements.

- The sample extraction probes within the stacks will follow, in general; design guidelines as presented in ANSI N13.1, 1969, Guide to Sampling Airborne Radioactive Materials in a Nuclear Facility. Sample probes are designed and operated to provide a near-isokinetic representative sample extraction based on the average stack velocity.

- The average stack velocity is determined from velocity profile measurements taken at or near the point of sample extraction. 
- Sample probes are located a minimum of five duct diameters downstream and two duct diameters upstream of major flow disturbance points in. the exhaust stack.

- Sample extraction probes are flange mounted to the stack to facilitate periodic remova?, inspection, and cleaning activities.

- Generic devices are used to provide fixed-filter-head record sampling, using a 47-millimeter filter holder, and a cartridge filled with silver zeolite to collect halogens, i.e., iodine-129.

- The record sampie airstream is collected through a 47-millimeter filter to obtain a particulate sample for laboratory analysis. A flow rate regulator is provided to maintain a constant flow rate through the collection filter assembly to compensate for filter loading effects. Audible and visible alarm signals indicating low sample flow are provided to the SAMCONS, which is linked to an area with frequent or continuous occupancy. Record sample filters are currently removed monthly and analyzed for total alpha and beta. Isotopic plutonium, strontium, and gamma analysis are performed on quarterly composites of the filters. Monthly analysis of silver zeolite cartridges is currently performed to quantify iodine-129 emissions.

- The record sample vacuum pump is ganged to exhaust fan operation via a switched receptacle in the system cabinet.

\subsection{LIQUID EFFLUENT SAMPLING AND MONITORING SYSTEM DESIGN CRITERIA}

Liquid radionuclide sampling is no longer applicable. 
HNF-EP-0468-4

\subsection{CHARACTERIZATION OF CURRENT EFFLUENT MONITORING SYSTEM}

Monitoring and sampling systems must be capable of verifying compliance with the discharge criteria for the specific effluent stream. Air $\mathrm{M} / \mathrm{S}$ requirements are well defined in NESHAPs (40 CFR 61, Subpart $H$ ). Monitoring and sampling of the air effluents will be conducted in accordance with HNF-POL-450.

\subsection{AIR EFFLUENT MONITORING SYSTEM DESCRIPTION AND SPECIFICATIONS}

As a result of the dose analysis presented in Section 4.0 , specific air $M / S$ requirements have been identified for the PUREX main stack. Monitoring requirements are continuous radiation monitoring (as defined by EPA in 40 CFR 61; this is fully met by continuous sampling and periodic analysis) and selective radionuclide monitoring. Continuous air monitoring requires filter analyses for total alpha and/or total beta radioactivity. Selective radionuclide monitoring analyzes the filters for specific radionuclide air concentrations.

\subsubsection{Monitoring/Sampling Requirements and Criteria}

Continuous air monitoring does not imply a real-time monitoring plan, but rather a system that samples continuously so that variations in effiuent concentrations are represented accurately by analysis. A continuous air sampler that draws air through and deposits particulates on a filter is an example. Both alpha and beta emitters are present in the PUREX main stack effluent; therefore, analysis of the sample filter in the laboratory includes both.

Stack monitoring requirements are discussed as follows. Table 7-1 summarizes the results of the dose analysis.

- Stack 291-A-1 will require radiation monitoring (EPA definition).

- Stack 291-A-1 will require continuous total alpha/beta monitoring.

- Stack 291-A-1 will require radionuclide selective analysis for p] utonium-239/240 and americium-241.

- The main stack at PUREX does not require monitoring for nonradiological hazardous or EPA criteria pollutants.

- Analysis for iodine-129 is not required. However, this will be continued as a best management practice, because iodine-129 does contribute approximately 50 percent of the actual dose to the Hanford Site MEI.

\subsubsection{Existing Air Effluent Monitoring/Sampling System}

The descriptions of the air effluent $M / S$ program and associated equipment used at the PUREX Plant are compiled from information included in existing 
effluent monitoring documents (WHC-SD-CP-EMP-004) and essential engineering drawings (HNF-SD-CP-TI-126).

7.1.2.1 291-A-1 Stack Monitoring/Sampling Description. Multipoint sample probes are located at three elevations on the main stack; 18 meters, 22.5 meters, and 27 meters. There are two sample probes at each location. Two of the six probes, one each at 18 and 22.5 meters, are used for effluent sampling record purposes. The remaining probes lead to monitors or samplers that were used for process control, which are not required during S\&M activities. Each of the record samplers consists of a filter through which a near-isokinetic ( \pm 20 percent) sample is pulled. Automatic flow controllers maintain the near-isokinetic sampling conditions.

The particulate filters from the record sampling unit are currently removed monthly and transferred to the WSCF laboratory for radiochemical analyses. The samples currently are analyzed monthly for gross alpha and beta and composited quarterly for specific radionuclide analyses. The silver zeolite cartridges for iodine analysis currently are collected and analyzed monthly.

7.1.2.3 Monitoring/Sampling Specifications and Deficiencies. Currently, the 291-A-1 Stack is continuously sampled for particulate radioactivity and monitored for flow rate.

A sampling probe provides the capability for analysis of all required radionuclides. The current design, location, and number of sample probes on the main stack are in compliance with ANSI N13.1. The current stack sampling system uses the best available technology and provides adequate assessment of stack emissions based on historical sample analysis data. The sampling system is well documented.

Many of the QA elements are addressed in the Quality Assurance Program P7an for Radionuclide Airborne Emissions Monitoring (WHC-EP-0536-3) and are further discussed in Section 9.1.

\subsection{REMAINING STACKS}

The 296-A-10 stack has been shut down and is now inactive. Future additions to the storage tunnel would require reactivation and upgrades to the stack. The remaining PUREX stacks (296-A-1, 296-A-2, 296-A-3, 296-A-5A, 296-A-5B, 296A-6, 296-A-7, 296-A-8, 296-A-14, and 296-A-24) have been shut down permanently and isolated, and a report of closure has been filed with the WDOH.

\subsection{AIR EFFLUENT SAMPLING PROGRAM}

The gaseous effluent in the main stack (291-A-1) will be continuously sampled and periodically analyzed for total alpha and beta radiation and specific radionuclides as the means to provide the required sensitivity. Air samples from 291-A-1 wi11 be analyzed for americium-241 and plutonium-239/240. Air samples from 291-A-1 currently are analyzed for iodine-129, as a best management practice. The $M / S$ program for air effluents is included in Table 7-2. Air sampling will comply with the criteria provided in applicable 
manuals and procedures. Stack flow measurements will comply with the criteria provided by the EPA in 40 CFR 61 .

\section{Stack 291-A-1}

Air sampling equipment is located at the 18 meter and 22.5 meter levels of the main stack. Samples are removed from the airstream by stack sampling probes SSP-V19-I and SSP-V18-2 and routed to the record sampler and the iodine sampler. Particles are collected on filters within the samplers. Flow through the system is monitored and controlled by flow controllers to ensure near-isokinetic sampling.

The particulate filters from the record sampling unit will be removed monthly and transferred to the WSCF laboratory for radiochemical analyses. These analyses will include americium-241 and plutonium-239/240 determinations. Samples currently are analyzed monthly for gross alpha and beta and composited quarterly for specific radionuclide analyses.

Table 7-1. Radioactive Sampling Requirements for Plutonium-Uranium Extraction Plant During Surveillance and Maintenance Mode.

\begin{tabular}{|l|c|c|}
\hline \multirow{2}{*}{ Stack } & \multicolumn{2}{|c|}{ Sampling/analysis requirements* } \\
\cline { 2 - 3 } & Total alpha/beta & $\begin{array}{c}\text { Selective } \\
\text { radionuclide(s) }\end{array}$ \\
\hline $291-\mathrm{A}-1$ & Yes & ${ }^{129} \mathrm{I},{ }^{239,240} \mathrm{Pu},{ }^{241} \mathrm{Am}$ \\
\hline
\end{tabular}

* Based on 40 CFR 61 , jodine is not required, but analyzed as a best management practice.

Table 7-2. Monitoring/Sampling and Analysis Program for Air Effluents.

\begin{tabular}{|c|c|c|c|l|}
\hline $\begin{array}{c}\text { Monitor/sample } \\
\text { location }\end{array}$ & Analytes & $\begin{array}{c}\text { Sample } \\
\text { frequency }\end{array}$ & $\begin{array}{c}\text { Type of } \\
\text { event }\end{array}$ & Equipment type \\
\hline \multicolumn{5}{|c|}{ Stack 291-A-1 } \\
\hline SPL-V18-1 (74-ft) & ${ }^{129} \mathrm{I}$ & Monthly & $\mathrm{S}$ & $\begin{array}{l}\text { Silver zeolite } \\
\text { cartridge }\end{array}$ \\
\hline $\mathrm{SPL}-\mathrm{V} 19-1(60-\mathrm{ft})$ & ${ }^{239 / 240} \mathrm{Pu},{ }^{241} \mathrm{Am}$ & Monthly. & $\mathrm{S}$ & Record sampler \\
\hline
\end{tabular}


HNF-EP-0468-4

This page intentionaliy left blank. 


\subsection{HISTORICAL. MONITORING/SAMPLING DATA FOR EFFLUENT STREAMS}

Normal and upset conditions for air and liquid effluents are discussed in the following sections.

\subsection{AIR EFFLUENTS}

Historical air effluent $M / S$ data have been assembled in annual reports. These reports typically recorded the routine releases, unusual occurrences (i.e., upset conditions), sample points, analytical data sheets, instrument calibration records and other information (e.g., WHC-EP-0573-4).

Section 4.1 .2 describes the upset operating conditions of the main stack.

\subsection{LIQUID EFFLUENTS}

Historical 1 iquid $M / S$ data have been assembled in various reports. Routine operations and releases, upsets, sample points, analytical data sheets and other information typically were recorded (WHC-SD-CP-EMP-006 and WHC-EP-0342).

There are no longer liquid effluent discharges and no applicable upset operating conditions. 
HNF-EP-0468-4

This page intentionally left blank. 
HNF-EP-0468-4

\subsection{SAMPLE ANALYSIS}

The analytical and laboratory procedures for the FEMP activities are identified in two quality assurance project plans (QAPjP), one quality assurance program $p$ lan (QAPP), and the annual statement of work as follows:

- WHC-EP-0446-2, Quality Assurance Project Plan for the Facility Effluent Monitoring Plan Activities

- WHC-EP-0536-3, Quality Assurance Program Plan for Radionuclide Airborne Emissions Monitoring

- WHC-EP-0528-2, Quality Assurance Project Plan for Radioactive Emissions Data

- HNF-EP-0835-2, Statement of Work for Services Provided by the Waste Sampling and Characterization Facility for the Effluent and Environmental Program during Calendar Year 1997.

Record sampling requirements will be conducted according to the Air Quality Program policy (HNF-POL-450).

Sample identification is initiated by the operations group taking the sample. Sampling personnel use the ABCASH system to provide sample identification and chain of custody, which is performed electronically through ABCASH. Sample custody is transferred when the properly marked sample is received by the analytical laboratory.

Sample collection and chain of custody at the PUREX Facility are currently addressed in the PUREX desk instructions and plant operating procedures, which are maintained on site. These procedures will be effective until the facility is turned over to BHI. At that time, sample collection and chain of custody will be addressed by BHI field support procedures.

Samples from the PUREX Facility main stack are transferred to WSCF 1 aboratory and analyzed according to requirements in the WSCF QAPP and individual analytical laboratory procedures.

Tracking of radioactive airborne emissions sample data is controlled by the Fluor Daniel Hanford, Inc. (FDH) team through assignment of unique electronic processing codes (EDP) for each sample location. These EDP codes are used by WSCF to report the results in accordance with the QAPjP for radioactive emissions data (WHC-EP-0582-2). 
HNF-EP-0468-4

This page intentionally left blank. 
HNF-EP-0468-4

\subsection{NOTIFICATION AND REPORTING REQUIREMENTS}

Notification and reporting requirements are imposed by federal and state law as well as by DOE Orders. This section serves as a guideline for general notification and reporting requirements and as a reference to the sources where specific information can be found for federal, state, and DOE requirements.

\subsection{OCCURRENCE CATEGORIZATION, NOTIFICATION, AND REPORTING}

Notifications and reporting of specific events related to environmental releases and/or events involving effluents and/or hazardous materials will be made in accordance with DOE Orders 5400.1, 5484.1, and 232.1. Specific implementation where required, is included in the PUREX Plant desk instructions, which are maintained on site.

\subsection{FEDERAL REQUIREMENTS}

The following federal requirements are applicable.

\subsubsection{Resource Conservation and Recovery Act of 1976}

RCRA requires biennial reports to be submitted to the regional administrator of the EPA. The 40 CFR 262, Subpart D, sets forth the reporting requirements for generators of hazardous waste that ship waste offsite, or store, treat, or dispose of hazardous waste onsite.

Owners or operators of treatment, storage, or disposal (TSD) facilities must comply with the reporting requirements contained in 40 CFR 264, Subpart E and 40 CFR 265, Subpart E.

\subsubsection{Comprehensive Environmental Response, Compensation, and Liability Act of 1980}

The 40 CFR 302 contains reportable quantities and notification requirements for releases of hazardous substances as designated by CERCL.A.

\subsubsection{National Emission Standards for Hazardous Air Pollutants}

Compliance and reporting requirements for DOE facilities emitting radionuclides other than radon are contained in 40 CFR 61 , Subpart $H$. The NESHAP requires that an annual report be submitted to EPA headquarters and the appropriate regional office. 
HNF-EP-0468-4

\subsection{STATE REQUIREMENTS}

The following state requirements are applicable.

\subsubsection{Generator Reporting}

Generator reporting requirements are found in WAC 173-303-220. Washington State requires that annual reports covering the preceding year be submitted by March 1 to Ecology.

\subsubsection{Facility Reporting}

Owners or operators of TSD facilities also are required to prepare and submit annual reports. These must be submitted by March 1 and cover facility activities for the previous year. The specific content requirements are specified in WAC 173-303-390.

The PUREX Facility, excluding the PUREX Storage Tunnels, is an interim status RCRA treatment and storage unit subject to 40 CFR 265 and WAC 173-303 reporting requirements. The PUREX Storage Tunnels, consisting of Tunnel Number 1 and Tunnel Number 2, are a final status RCRA storage unit subject 40 CFR 264 and WAC 173-303 reporting requirements. During the S\&M phase, hazardous and/or dangerous waste is not anticipated to be generated or discharged. Therefore, compliance with the above federal and state reporting requirements regarding annual reports would indicate no activity. In the event facility operations were to change, reporting content would be modified as appropriate. 


\subsection{INTERFACE WITH NEAR-FACILITY MONITORING}

The sitewide EMP (DOE/RL-91-50, Rev. I) consists of two distinct but related components; environmental surveillance conducted by PNNL and effluent monitoring conducted by the FDH team. Environmental surveillance consists of surveillance of all environmental parameters to demonstrate compliance with regulations. Effluent monitoring includes both in-line and facility effluent monitoring as well as near-facility environmental monitoring. Projected EDEs, reported in this FEMP, are the products of effluent monitoring. Near-field monitoring is required in accordance with procedures described in the operational environmental monitoring QAPJP (WHC-EP-0538-2).

\subsection{PURPOSE}

Near-Facility Monitoring (NFM) provides facility-specific environmental monitoring to protect the environment adjacent to facilities under the responsibility of the FDH team and to ensure compliance with federal, state, and local environmental regulations.

The objectives of the NFM are to evaluate the following:

- Compliance with DOE, EPA, Ecology, WDOH, and internal FDH team environmental radiation protection requirements and guidelines

- Performance of radioactive waste confinement systems

- Trends regarding radioactive materials in the environment at and adjacent to nuclear facilities and waste disposal sites.

Specifically, the NFM is developed to:

- Monitor all inactive, existing, and new low-level waste disposal sites to assess both radiological and nonradiological hazards (DOE Order $5820.2 A)$

- Determine the effectiveness of effluent treatment and controls in reducing effluents and emissions (DOE/EH-0173T)

- Detect and quantify unplanned releases (DOE/EH-0173T) (40 CFR 302) (WAC 173-303-145) (DOE Order-232.1) (DOE 5484.1)

- Monitor fugitive emissions and diffuse sources from contaminated areas for compliance with NESHAPs (40 CFR 61), (DOE/EH-0173T), Toxic Air Emissions Inventory (40 CFR 265, Subparts AA \& B13), State Operating Permit Program (40 CFR 70), and Source Registration (WAC 246-247)

- Monitor all surplus facilities before decontaminating or decommissioning (DOE Order 5820.2A)

- Monitor new and existing sites, processes, and facilities for potential impacts and releases (DOE Order 5484.1 and DOE/EH-0173T) 
- Monitor and assess radioactive contamination and potential exposure to employees and the public (DOE Orders 5400.1 \& 5400.5).

The purpose and justification for the NFM is contained in WHC-CM-7-4, Operational Environmental Monitoring (WHC 1992). The primary justification for the NFM includes the following:

- The NFM provides a level of assurance to the FDH team that the effluent and contamination controls for the various facilities and waste sites are effective

- A secondary aspect of the NFM is additional assurance beyond that provided by the occupational health and safety program that it is safe to work onsite and for visitors to safely tour the site.

\subsection{BASIS}

Near-facility monitoring is conducted to (1) monitor employee protection; (2) monitor environmental protection; and (3) ensure compliance with federal, state, and local regulations.

\subsection{MEDIA SAMPLED AND ANALYSES PERFORMED}

Procedure protocols for sampling, analysis, data handling, and reporting are specified in WHC-CM-7-4. Media include ambient air, surface water, groundwater, external radiation dose, soil, sediment, vegetation, and animals at or near active and inactive facilities and/or waste sites. Parameters monitored include the following, as needed: $\mathrm{pH}$, water temperature, radionuclides, radiation exposure, and hazardous constituents. Animals that are not contaminated, as determined by a field instrument survey, are released to a nonhazardous environment.

\subsection{LOCATIONS}

Samples are collected from known or suspected effluent pathways (e.g., downwind of potential releases, liquid streams, or proximal to release points). To avoid duplication, the FDH team relies on existing sample locations where PNNL previously has established sample sites (e.g., air samplers in the 300 Area). There are approximately (numbers and locations could vary year to year) 47 air samplers (8 in the 100 Area, 37 in the 200/600 Areas, 1 at the 300 Area Treated Effluent Disposal Facility, and 1 collocated with samplers operated with WDOH and PNNL at the Wye Barricade), 24 surface water sample sites (22 in the 100 Area and 2 in the 200/600 Areas), 110 groundwater monitoring wells (20 in the 100 Area, 89 in the 200/600 Areas, and 1 in the $300 / 400$ Areas); 299 external radiation monitor point:s (182 survey points and 41 TLD sites in the 100 Area, 61 TLD sites in the 200/600 Areas, and 15 TLD sites in the $300 / 400$ Areas); 157 soil sample sites ( 32 in the 100 Area, 110 in the 200/600 Areas, and 15 in the 300/400 Areas); and 95 vegetation sample sites (40 in the 100 Area, 40 in the $200 / 600$ Areas, and 15 in the $300 / 400$ Areas). Animal samples are collected at or near facilities and/or waste sites. Specific locations of sample sites are found in WHC-SP-0098-8. 
Surveys to detect surface radiological contamination, scheduled in WHC-SP-0098-8, are conducted near and on liquid waste disposal sites (e.g., cribs, trenches, drains, retention basin perimeters, pond perimeters, and ditch banks), solid waste disposal sites (e.g., burial grounds and trenches), unplanned release sites, tank farm perimeters, stabilized waste disposal sites, roads, and firebreaks in the operational areas. There are 391 sites in the operational areas (100 in the 100 Area, 273 in the $200 / 600$ Areas, and 18 in the 300/400 Areas) where radiological surveys are conducted.

\subsection{PROGRAM REVIEW}

The NFM wil1 be reviewed at least annually to determine that the appropriate effluents are being monitored and that the monitor locations are in position to best determine potential releases.

\subsection{SAMPLER DESIGN}

Sampler design (e.g., air monitors) will be reviewed at least biannually to determine equipment efficiency and compliance with current EPA and industry [e.g., ANSI and American Society for Testing and Materials (ASTM)] standards.

\subsection{COMMUNICATION}

The FDH team and the research and development contractor (PNNL) will compare and communicate results of their respective monitoring programs at least quarterly and as soon as possible under upset conditions.

\subsection{REPORTS}

Results of the NFM are published in annual reports, such as Environmental Re7eases for Calendar Year 1995, WHC-EP-0527-5, Environmental Surveil7ance Annual Report Calendar Year 1995, WHC-EP-0573-4, and Radionuclide Air Emissions Report for the Hanford Site, Calendar Year 1995 (DOE/RL-96-37). The radionuclide values in these reports are expressed in curies, or portions thereof, for each radionuclide per unit weight of sample (e.g., picocuries per gram) or in field instrument values (e.g., counts per minute). Values are reported in this manner, rather than EDE, which is calculated as the summation of the products of the dose equivalent received by specified tissues of the body and a tissue-specific weighting factor. 
HNF-EP-0468-4

This page intentionally left blank. 


\subsection{QUALITY ASSURANCE}

The QAPJP (WHC-EP-0446-2) describes the QA requirements associated with implementing FEMPs. The $\mathrm{plan}$ identifies the FEMP activities and assigns the appropriate QA requirements. The QAPJP will be consistent with the requirements in DOE Order 5700.6C. In addition, QA requirements in 40 CFR 61 , Appendix B, Method 114, wi 11 be considered when performing monitoring calculations and estabijishing monitoring systems for airborne emissions.

\subsection{OBJECTIVE}

The objective of this $\mathrm{plan}$ is to provide a documented $Q A \mathrm{pl}$ an describing QA requirements for implementing FEMP activities at the PUREX Facility.

\subsection{REQUIREMENTS}

A QAPP (WHC-EP-0536-3) and a QAPJP (WHC-EP-0528-2) have been developed to implement the overall $Q A$ program requirements for radioactive airborne emissions data collection and reporting activities. The QAPjP (WHC-EP-0446-2) applies specifically to the field activities, Taboratory analyses, and continuous monitoring performed for al7 FEMPS by the FDH team. 


$$
\text { HNF-EP-0468-4 }
$$

This page intentionally left blank. 


\subsection{INTERNAL AND EXTERNAL PLAN REVIEW}

DOE Order 5400.1, Chapter IV.4, requires the facility effluent monitoring $\mathrm{p} 7$ an be reviewed annually and updated every 3 years. The FEMP should be reviewed and updated as necessary after each major change or modification in the facility processes, facility structure, ventilation and liquid collection systems, monitoring equipment, or waste treatment, or for a significant change to the safety analysis reports. In addition, EPA regulations require that records on the results of radioactive airborne emissions monitoring be maintained onsite for 5 years. Operations management will maintain records of reports on measurements of stack particulates or other nonradioactive hazardous pollutant emissions for 3 years.

The Effluent and Emissions Monitoring organization prepares an annual effluent discharge report for each area on the Hanford Site to cover both airborne and liquid release pathways. In addition, a report on the air emissions and compliance to the NESHAP is prepared by Effluent and Emission Monitoring and submitted to EPA as well as to DOE Headquarters.

Facility management is required to obtain the Effluent and Emission Monitoring function's approval for all changes to the FEMPs, including those generated in the annual review and update.

Contractor management is responsible for assigning appropriate personnel to perform the reviews, assessments, and approvals as required, and for maintaining this documentation. The DOE-RL may require additional reviews, as necessary, to ensure program integrity. 


\section{HNF-EP-0468-4}

This page intentionally left blank. 
HNF-EP-0468-4

\subsection{COMPLIANCE ASSESSMENT}

A comparison of $M / S$ system capabilities with regulatory and other requirements was conducted to determine which areas were not in compliance. This section summarizes that comparison. A detailed point-by-point evaluation of the NESHAP requirements in 40 CFR 61 is included in WHC-EP-0545.

\subsection{COMPLIANCE ASSESSMENT}

The following sections discuss the compliance assessment.

\subsubsection{Comparison of Instrument Specifications with Required Standard}

The existing air effluent $M / S$ system of near-isokinetic continuous sampling with periodic analysis of the resultant samples complies with 40 CFR 61, Subpart H. Laboratory analys is and chain-of-custody procedures are adequate to maintain sample accuracy and reliability. QA elements are addressed in the Quality Assurance Program Plan for Radionuclide Airborne Emissions Monitoring, WHC-EP-0536-3.

\subsubsection{Comparison of Instrument Specifications with Monitoring Criteria}

The current air monitoring systems with its capability of continuous, near-isokinetic sampling followed by periodic analyses achieve full compliance with monitoring criteria.

\subsubsection{Comparison of Instrument Specifications with Effluent Characteristics}

Existing monitoring equipment for the air effluent stream has the capabitity to accurately characterize the stream's general parameters such as flow rate and loss of flow. These general parameters al so are appropriate to indicate changes in the effluent. Laboratory analysis can be selected to characterize any desired effluent parameter.

\subsubsection{Comparison of Projected Effluent Characteristics with Historical Data}

Historical data used to project effluent characteristics throughout this FEMP reflect transition to shutdown conditions at PUREX. Projected emissions characteristics during S\&M should remain the same or continue to drop from the most recent historical data, which reflect transition to shutdown conditions.

\subsubsection{Comparison of Effluent Monitoring Capabilities with Regulatory and Contractor Requirements}

Effluent monitoring capabilities for air discharges meet both regulatory and FDH team requirements. 


$$
\text { HNF-EP-0468-4 }
$$

\subsection{EXEMPTIONS}

No current or pending exemptions have been identified.

\subsection{SYSTEM UPGRADES REQUIRED FOR COMPLIANCE}

No system upgrades currently are required.

\subsection{CLEAN AIR ACT REQUIREMENTS}

The NESHAP requirements in 40 CFR 61 for the main stack are discussed in WHC-EP-0545. 


\section{HNF-EP-0468-4}

\subsection{SUMMARY AND CONCLUSIONS}

Monitoring and sampling requirements and system upgrades are discussed in the following sections.

\subsection{MONITORING AND SAMPLING REQUIREMENTS FOR AIR EFFLUENTS}

Continuous sampling and periodic laboratory analysis are required for the main stack, 291-A-1. The 291-A-1 stack will require continuous sampling for particulates, with analysis for total alpha, total beta, plutonium-239/240, and americium-24l.

\subsection{SYSTEMS UPGRADES FOR AIR MONITORING/SAMPLING}

The existing equipment at the 291-A-1 stack will not require a system upgrade to meet the sampling needs. Either one of the existing isokinetic sampling systems installed at the 18 meter and 22.5 meter elevations have been determined to be adequate for ensuring a representative sample is collected. 
HNF-EP-0468-4

This page intentionally left blank. 


\subsection{REFERENCES}

ANSI N13.1, Guide to Sampling Airborne Radioactive Materials in a Nuclear Facility, American National Standards Institute, Washington, D.C.

ANSI, 1974, Specification and Performances of On-Site Instrumentation for Continuous7y Monitoring Radioactivity in Effluents, American National Standards Institute, Washington, D.C.

DOE/EH-0173T, Environmental Regulatory Guide for Radiologica7 Effluent Monitoring and Environmental Surveill ance, 1991, U.S. Department of Energy, Washington D.C.

DOE Order 231.1, Environment, Safety, and Health Reporting, as revised, U.S. Department of Energy, Washington D.C.

DOE Order 232.2, Occurrence Reporting and Processing of Operations Information, as revised, U.S. Department of Energy, Washington D.C.

DOE Order 5000.3B, Occurrence Reporting and Processing of Operations Information, as revised, U.S. Department of Energy, Washington D.C.

DOE Order 5400.1, General Environmental Protection Program, as revised, U.S. Department of Energy, Washington, D.C.

DOE Order 5400:5, Radiation Protection of the Public and the Environment, as revised, U.S. Department of Energy, Washington D.C.

DOE Order 5480.4, Environmental Protection, Safety, and Health Protection Standards, as revised, U.S. Department of Energy, Washington D.C.

DOE Order 5484.1, Environmental Protection, Safety, and Health Protection Information Reporting Requirements, as revised, U.S. Department of Energy, Washington, D.C.

DOE Order 5700.6C, Quality Assurance, as revised, U.S. Department of Energy, Washington D.C.

DOE Order 5820.2A, Radioactive Waste Management, as revised, U.S. Department of Energy, Washington D.C.

D0E/RL-91-50, Environmenta7 Monitoring Plan, Rev. 1, U.S. Department of Energy, Richland 0perations Office, Richland, Washington.

DOE/RL-96-37, Radionuclide Air Emissions Report for the Hanford Site, Calendar Year 1995, U.S. Department of Energy, Richland Operations Office, Richland, Washington.

DOE/RL-96-68, Hanford Analytical Services Quality Assurance Requirements Documents, U. S. Department of Energy, Richland Operations Office, Richland, Washington 
Ecology, EPA, and DOE, 1996, Hanford Federal Facility Agreement and Consent Order, as amended, Washington State Department of Ecology,

U.S. Environmenta1 Protection Agency, U.S. Department of Energy, 01ympia, Washington.

EPA, 1986, Test Methods for Evaluating Solid Waste, SW-846, 3rd Ed., U.S. Environmental Protection Agency, Washington, D.C.

HNF-EP-0835-2, Statement of Work for Services Provided by the Waste Sampling and Characterization Facility for the Effluent and Environmental Program during Calendar Year 1997, Project Hanford Management Contractor, Richl and, Washington, 1997.

HNF-POL-450, Air Quality Program, Project Hanford Management Contractor, Rich1 and, Washington, 1997.

HNF-SD-CP-TI-126, PUREX Plant Essential \& Support Drawing List, Rev. 8, Project Hanford Management Contractor, Richland, Washington, 1997.

WHC-CM-4-2, Quality Assurance Manual, Westinghouse Hanford Company, Rich1 and, Washington.

WHC-EP-0342, Stream-Specific Reports, Addendum 2, PUREX Plant Chemica7 Sewer; Addendum 5, PUREX Plant Steam Condensate; Addendum 12, PUREX Plant Process Condensate; Addendum 14, PUREX Plant Ammoni a Scrubber Condensate; and Addendum 20, PUREX Plant Cooling Water; Westinghouse Hanford Company, Richland, Washington.

WHC-EP-0446-2, Quality Assurance Project Plan for Facility Effluent Monitoring Plan Activities, Westinghouse Hanford Company, Richland, Washington.

WHC-EP-0498, Unit Dose Calculation Methods and Summary of Facility Effluent Monitoring P7an Determinations, Westinghouse Hanford Company, Richland, Washington.

WHC-EP-0527, Environmenta7 Releases for Calendar Year 1991, Revisions 1 through 5, 1992 to 1996, Westinghouse. Hanford Company, Richland, Washington.

WHC-EP-0528-2, Effluent Monitoring Quality Assurance Project P7an for Radioactive Emissions Data, Westinghouse Hanford Company, Richland, Washington.

WHC-EP-0536-3, Quality Assurance Program P7an for Radionuclide Airborne Emissions Monitoring, Westinghouse Hanford Company, Richland, Washington.

WHC-EP-0538-2, Operational Environmental Monitoring Program Quality Assurance Project Plan, Westinghouse Hanford Company, Richland, Washington.

WHC-EP-0545, PUREX P7ant Comparison with 40 CFR 61, Subpart H, and other Referenced Guidelines for Stack 291-A-1, Westinghouse Hanford Company, Richland, Washington, 1992.

WHC-EP-0573-4, Environmental Surveillance Annual Report Calendar Year 1995, Westinghouse Hanford Company, Richland, Washington. 


\section{HNF-EP-0468-4}

WHC-SD-CP-EMP-004, Effluent Monitoring Plan PUREX Gaseous Effluents, as amended, Westinghouse Hanford Company, Richland, Washington.

WHC-SD-CP-EMP-006, PUREX Liquid Effluent Monitoring P7an, Westinghouse Hanford Company, Richland, Washington.

WHC-SP-0098-8, Routine Environmental Monitoring Schedule Calendar Year 1997, Westinghouse Hanford Company, Richland, Washington. 
HNF-EP-0468-4

This page intentionally left blank. 


\section{DISTRIBUTION}

U.S. Department of Energy, Richland Operations Office

G. M. Bel1

A5-52

C. R. Briggs

C. E. Clark

A5-55

S. E. Clarke

A5- 15

R. X. Gonzalez

A5-15

R3 -79

J. B. Ha]l

A5- 15

D. C. Ward

A5-15

Public Reading Room

$\mathrm{H} 2-53$

Environmental Restoration Contractor

G. A. Blunt

R. J. Landon

G. M. McFarlan

J. E. Rugg

J. G. Woolard

HO-09

HO-18

$\times 5-53$

$\times 5-53$

HO-17

Pacific Northwest National Laboratory

G. R. Hoenes

P7-79

G. A. Simiele

P7-79

R. K. Woodruff

P7-68

Hanford Technical Library

K1-11

Eluor Daniel Hanford, Inc.

J. A. Bates

H6-23

S. M. Price

$\mathrm{H} 6-23$

D. G. Ranade

H8-66

G. W. Reddick

N1-26

B\&W Hanford Company

R. W. Bailey

S6-15

K. A. Hadley.

R3-56

D. L. Johnson

S6-01

G. 3. Lebaron (2)

S6-19

S. T. Noga

S6-21

W. A. Peiffer

S6-19

L. C. Zinsli

S6-19 
HNF-EP-0468-4

DISTRIBUTION

Waste Management Federal Services of Hanford, Inc.

W. E. Davis

L. P. Diediker (5)

H6-36

T. P. Frazier

H6-36

D. W. Fritz (5)

H6-25

E. M. Greager

R. E. Johnson (5)

H6-36

H6-36

H6-25

D. L. Mitche11

H6-29

W. R. Thackaberry

H6-32

Waste Management Federal Services, Inc.

Northwest Operations

J. J. Dorian

$\mathrm{HI}-13$

Lockheed Martin Services, Inc.

Central Files

DPC

A3-88

EDMC (2)

H6-08

H6-08

Distr-2 